\title{
LA INMUNIDAD ABSOLUTA DEL ÁRBITRO: UNA EQUIVOCACIÓN CON ORÍGENES HISTÓRICOS
}

\section{THE ABSOLUTE IMMUNITY OF THE ARBITRATOR: A MISTAKE WITH HISTORICAL ORIGINS}

\author{
Pedro J. Martínez-Fraga* \\ Profesor Adjunto de Derecho Internacional \\ New York University
}

Recibido: 08.05.2020 / Aceptado: 26.05.2020

DOI: https://doi.org/10.20318/cdt.2020.5621

\begin{abstract}
Resumen: Este texto explora el desarrollo de la doctrina de la inmunidad del árbitro y su situación actual en el marco del derecho consuetudinario de los Estados Unidos. Para ello, examina la forma en que la doctrina se ha desarrollado en otras jurisdicciones del common law y de derecho civil, proporcionando un contexto y un contraste. Asimismo, indaga por qué Estados Unidos es el único país que concede una inmunidad absoluta al árbitro. Se analizan las decisiones posteriores a la guerra civil que desempeñaron un papel fundamental en la formación de la doctrina. Finalmente, se hace hincapié en la cuestión del "por qué" en lugar del "qué", así la metodología y el razonamiento jurídico adquieren mayor relevancia que las propias conclusiones.
\end{abstract}

Palabras clave: inmunidad, árbitro, doctrina, responsabilidad civil.

Abstract: This text explores the development of the arbitrator immunity doctrine and its current status under United States common law. In doing so, it examines the manner in which the doctrine has developed in other common law and civil law jurisdictions to provide both a context and a contrast. The text also explores why the United States stands alone in the international community in according arbitrators absolute immunity from civil claims. The text analyzes post-civil war decisions that played a key role in the formation of the doctrine. Finally, it emphasizes the "why" instead of the "what", and in thus doing posits that methodology and legal reasoning are more important than final conclusions.

Keywords: immunity, arbitrator, doctrine, civil claims.

Sumario: Introducción. I. Los orígenes de la Doctrina de Inmunidad Absoluta que se asocia a los jueces: Comienzos de una asunción no probada. 1) El rey no puede hacer nada mal: Una palabra sobre la inmunidad judicial. 2) La inmunidad judicial que dio lugar a la inmunidad del arbitro: Un paradigma falso. 3) La Corte Suprema de Estados Unidos aborda la inmunidad judicial: El magistrado Stephen J. Field y los casos emblemáticos Randall v. Brigham y Bradley v. Fisher. II. El

\footnotetext{
* Pedro J. Martínez-Fraga es socio de la firma Bryan Cave Leighton Paisner LLP, donde se desempeña como Codirector del Grupo de la práctica de Arbitraje Internacional. En 2015, el presidente Barack Obama designó al Sr. Martínez-Fraga para formar parte del Panel de Conciliadores del Centro Internacional de Arreglo de Diferencias Relativas a Inversiones del Banco Mundial. Asimismo, se ha desempeñado como asesor principal de nueve países en disputas internacionales. Ha publicado ocho libros y ha sido publicado en quince países, en cinco idiomas. Es profesor adjunto de Derecho en la Universidad de Nueva York y profesor visitante de Derecho en la Universidad de Navarra, en Pamplona, España. El Sr. Martínez-Fraga es graduado de St. John's College (Annapolis) (B.A., Institutional Honors), egresado de la Facultad de Derecho de la Universidad de Columbia (J.D., Harlan Fiske Stone Scholar), y posee un doctorado en Derecho Internacional Privado y Público de la Universidad de Madrid (Cum Laude).
} 
efecto de la reconstrucción de la guerra civil en el desarrollo de la doctrina. 1) Ex Parte Milligan. 2) Los casos de juramento de prueba: Cummings v. Missouri y Ex Parte Garland. 3) Bradley v. Fisher: La maduración de la inmunidad judicial. III. La transposición de la inmunidad judicial a la inmunidad arbitral: el cambio de paradigma que conduce a la sobreprotección sin fundamento normativo, histórico o de políticas. Conclusión.

\section{Introducción}

1. Los Estados Unidos se erige en solitario como el único país en la comunidad internacional de naciones que proporciona inmunidad absoluta a los árbitros respecto de las acciones civiles. Mientras que la mayoría de los países se suscriben a un modelo contractual, Estados Unidos sigue un paradigma de adjudicación judicial, que interpreta lo privado como público y desecha un análisis de proveedores de servicios de mercado. Este estatus anómalo es útil. Obliga a hacer las preguntas difíciles.

2. ¿Es la divergente postura que los Estados Unidos han adoptado sobre esta cuestión una consecuencia de políticas sociopolíticas intencionalmente diseñadas para ser establecidas? ¿Por qué los Estados Unidos son la singular nota disonante en comparación con el resto del mundo? ¿Cómo se ha desplegado el desarrollo doctrinal de la inmunidad del árbitro en los Estados Unidos de tal manera, que sólo el derecho consuetudinario de los Estados Unidos concede a los árbitros inmunidad absoluta al enjuiciamiento civil? ¿Es una cuestión de derecho consuetudinario versus el desarrollo conceptual del derecho civil? Si es así, ¿por qué, entonces, la posición de Estados Unidos sobre el tema está también en desacuerdo con todas las demás jurisdicciones de derecho consuetudinario? En la medida en que una política de este tipo no sea la consecuencia explícita y deliberada del diseño, ¿cómo de otra forma pudo haberse desarrollado? Por supuesto, no hay una sola respuesta.

3. Una confluencia de eventos y accidentes al principio tuvo que alinearse perfectamente como un predicado para producir este acorde discordante. Primero, la naturaleza misma de la adjudicación del árbitro es algo así como una especie híbrida. Los árbitros son actores privados que presiden disputas privadas, generalmente derivadas de transacciones comerciales que individuos han celebrado en condiciones de mercado. Sin embargo, su principal compromiso es adjudicar tales disputas.

4. La inevitable e inconfundible analogía con la adjudicación judicial es seductivamente acogedora. Al igual que sus contrapartes judiciales, los árbitros serían privados del ejercicio de un juicio independiente si estuvieran preocupados por posibles, si no totalmente probables, demandas contra ellos provenientes de descontentas partes no prevalecientes. Aunque no ha sido corroborado en absoluto por los datos empíricos que pueden encontrarse en las jurisdicciones de derecho civil, la adjudicación del árbitro se vería negativamente comprometida si éstos estuvieran sujetos a juicios civiles con base en la negligencia o el incumplimiento de obligaciones contractuales.

5. La necesidad de garantizar la independencia y el justo criterio en la adjudicación arbitral, dice el argumento, comanda una absoluta protección contra reclamos civiles que no se proporciona a ningún otro tipo de profesional que se involucre en mala praxis, viole expresamente una obligación contractual o, simplemente, sea negligente. En este sentido, los árbitros son únicos. Su "singularidad", a su vez, requiere una inmunidad especial o calificada como una cuestión de derecho. Así, la dualidad inherente al papel de un árbitro en parte puede haber contribuido a la inmunidad absoluta de que el derecho consuetudinario de los Estados Unidos subvenciona a tales actores. Sin embargo, el peso que debe concederse a este factor sigue siendo menos claro.

6. Un segundo elemento que contribuye al tratamiento idiosincrásico del derecho consuetudinario de los Estados Unidos sobre el tema se puede rastrear en el Derecho consuetudinario inglés. El axioma de Henry de Bracton y más tarde el de William Blackstone sobre que "el rey no puede hacer 
mal", e incluso es incapaz de pensar lo que está en contra de los mejores intereses del bien común, puede de hecho haber contribuido a la naturaleza absoluta de la protección contra acciones civiles que el derecho consuetudinario de los Estados Unidos extiende a los árbitros. La inmunidad absoluta del rey fue extendida a aquellos más inmediatamente encargados de ejecutar los imperativos monárquicos. Como administradores directos de la justicia que los monarcas proporcionan a sus súbditos, parece simplemente "natural" que a los jueces se les invista de un nivel absoluto de protección. La absoluta inmunidad judicial contra las acciones civiles está sólo a la mitad de un paso de la inmunidad absoluta del árbitro. Después de todo, ciertamente, a primera vista, la adjudicación del árbitro no parece diferente de su contraparte judicial.

7. Un tercer factor contribuyente para el desarrollo de la doctrina de la inmunidad del árbitro del derecho consuetudinario de los Estados puede encontrarse en un razonamiento jurídico (i) con base en la analogía que (ii) vio oscurecidas las características definitorias de ambos, árbitros y jueces. Por lo tanto, la doctrina de la "inmunidad judicial" fue aplicada reflexivamente a los árbitros.

8. Más adelante en el tiempo, sin identificar las razones o motivos, la aplicación de la inmunidad judicial a los árbitros, bloqueando de manera absoluta las reivindicaciones civiles, se convirtió en la doctrina de inmunidad del árbitro. Sin mucha fanfarria inmunidad del árbitro sustituyó a la aplicación de la inmunidad judicial a los árbitros. Por lo tanto, la aplicación indiscriminada de una doctrina a los árbitros, a través de un uso mecánico del lenguaje y el cambio prácticamente imperceptible en el uso, dio lugar a una nueva doctrina con nombre propio que pronto se puso de moda.

9. Tomando prestado como idéntico el análisis relativo a la doctrina de la inmunidad judicial contra el procesamiento civil, y reforzándolo con el brillo de una argumentación sólo sustentada en la analogía, la inmunidad absoluta del árbitro contra los procedimientos civiles asumió una vida propia. El atractivo de la argumentación por analogía y el trato, algo flojo y habitual, por parte de los tribunales de la aplicación indiscriminada de la inmunidad judicial a los árbitros, ciertamente contribuyeron a la posición única del derecho consuetudinario de los Estados Unidos sobre esta cuestión.

10. Un cuarto factor contribuyente es quizás fácilmente identificable en el "regla hecha regla aplicada" propio de la cultura del derecho consuetudinario. La inconsciente repetición por parte de los tribunales que participan en la aplicación del "stare decisis", asumida implícitamente y, más generalmente, derivada suposiciones no probadas, está en el corazón de la singular la perspectiva del derecho consuetudinario de los Estados Unidos sobre este problema.

11. Véase la aplicación de precedentes como un asunto táctico y no como un asunto estratégico, que invita al pensamiento crítico del principio a aplicar, constituye un régimen judicial común en la formación de la ley. Una vez que un problema se identifica fácilmente para la adjudicación, no es raro que un tribunal repita los errores derivados del uso mecánico del lenguaje. En este contexto, la estructura interna de las reglas es no analizada. Las reglas no se revisan. En cambio, la regla aplicable a la adjudicación es simplemente aplicada. Por lo tanto, los “árbitros son como jueces.” ¿Cómo son "diferentes de los jueces"? Nunca realmente se considera y, mucho menos, las razones por las que los jueces son tratados de una manera específica.

12. La metodología continúa. Debido a que los jueces adjudican, se les debe otorgar una inmunidad absoluta contra las acciones civiles que los litigantes descontentos probablemente presentarán. Los árbitros son como los jueces y, por lo tanto, a los árbitros también les debe conceder inmunidad absoluta al enjuiciamiento civil.

13. La republicación de premisas falsas, suposiciones no probadas, modelos de adjudicación sin base empírica, y una mecánica en el tratamiento del lenguaje, en conjunto, conspiran para dar lugar a una "inconsciente adjudicación" que se basa históricamente, pero que en realidad no considera los 
efectos de la historicidad en el análisis judicial y la elaboración de la ley. Estos elementos de la adjudicación del derecho consuetudinario de los Estados Unidos, también puede haber desempeñado el papel protagonista como causa de que el derecho consuetudinario de los Estados Unidos se destaque en solitario sobre este asunto.

14. Un quinto factor importante que afecta este desarrollo doctrinal único concierne a la Corte Suprema Estados Unidos de la reconstrucción post guerra civil. Debido a que los orígenes y el desarrollo de la doctrina de la inmunidad judicial no pueden separarse de la historia conceptual de la doctrina de la inmunidad del árbitro, la preocupación de la Corte de Estados Unidos de la reconstrucción post guerra civil por reforzar una rama judicial del gobierno, debe identificarse como un factor muy importante en el desarrollo de la doctrina de la inmunidad del árbitro. De notable importancia en este sentido fue la contribución del juez Stephen J. Field en los casos emblemáticos de Randall v. Brigham y Bradley v. Fisher. ${ }^{1}$

15. Cuando la elaboración judicial de la ley surgida de la repetición y la aplicación de suposiciones no probadas subyacentes a la doctrina, se transfieren de la inmunidad judicial a los árbitros, la historicidad relativa a la inmunidad judicial, sin consideración alguna, se importó al proceso de adjudicación del árbitro. Sin embargo, la historia que configura el desarrollo doctrinal de la inmunidad judicial simplemente no es, ni puede ser, aplicable a la doctrina de la inmunidad del árbitro.

16. Los acontecimientos, las políticas, los objetivos y el funcionamiento técnico de la doctrina de la inmunidad judicial son únicos para el poder judicial. Forman parte de un todo que contextualiza adecuadamente el alcance absoluto de la inmunidad judicial. Ninguno de estos elementos, sin embargo, puede ser injertado justificadamente en la doctrina de la inmunidad del árbitro.

17. La pregunta no es una que se refiera a un conflicto del derecho consuetudinario de los Estados Unidos con el resto del mundo, en un esfuerzo por determinar qué política se adapta mejor al objetivo de proteger la adjudicación del árbitro, promoviendo la independencia del pensamiento y juicio. En cambio, la postura única del derecho consuetudinario de los Estados Unidos sobre este problema sirve como una rica y acogedora placa de Petri para el análisis de la metodología de elaboración de la ley del derecho consuetudinario, que no puede estar en absoluto divorciado del contexto histórico y el razonamiento jurídico.

18. Este texto analiza el derecho consuetudinario de los Estados Unidos que aborda la inmunidad del árbitro en el marco de las cinco proposiciones identificadas anteriormente. Estas premisas no se presentan en ningún orden jerárquico. La importancia relativa evaluada desde la perspectiva de la causalidad es un desafío tanto insalvable como insignificante para los propósitos actuales. Lo que importa es la medida en que la historia y la "rutinaria" elaboración de la ley han contribuido a la formación y perpetuación de una doctrina de inmunidad que se encuentra en desacuerdo con los logros sobre el tema de todos los Estados que la han considerado. Por lo tanto, el texto aspira a ser más que una mera narrativa de desarrollo doctrinal.

19. Pretende invitar al derecho consuetudinario de los Estados Unidos a que siga reflexionando sobre sí mismo, pero para llevar a cabo esa introspección y autoexamen más allá de los limitados parámetros prácticos de análisis. En juego está más que sólo el alcance de la inmunidad que se concederá a los árbitros. Lo que es de consecuencia es cómo se forman los principios iniciales y la medida en la cual se someten al pensamiento crítico o son simplemente asumidos como verdaderos. En este mismo sentido, se vuelve igualmente crítico cuestionar hasta qué punto las premisas subyacentes del stare decisis deben ser revisadas en situaciones en las que no hay un cambio ostensible en circunstancias que aparentemente garantizan revisión.

${ }^{1}$ Randall v. Brigham, 74 U.S. 523 (1869); Bradley v. Fisher, 80 U.S. 335 (1871). 
20. Aquí la premisa de que la adjudicación del árbitro no es materialmente diferente de la adjudicación judicial, a los fines de la protección de inmunidad, ha sido abrazada como una verdad intuitiva y evidente. Parece casi ocupar el estatus de jus cogens. Por lo tanto, al igual que con todas las verdades evidentes, someterla a los rigores del razonamiento discursivo sólo puede servir para nublar y distanciar lo que es ya claro e inmediato.

21. La historia del desarrollo doctrinal de la inmunidad del árbitro sirve como pretexto e invitación para ver lo particular como pertinente sólo en la medida en que puede servir para enriquecer la comprensión de lo general. El recorrido conceptual de la doctrina de la inmunidad del árbitro es solo el más pequeño de los microcosmos a través de los cuales se puede estudiar la contribución gradual, y a veces no tan gradual, del derecho consuetudinario de los Estados Unidos a la formación y transformación de la doctrina. También es un incentivo a la conciencia para reflexionar sobre sí misma, pero sin perder la dirección del propósito.

\section{Los orígenes de la doctrina de inmunidad absoluta que se asocia a los jueces: los comienzos de una asunción no probada}

22. La dualidad conceptual que se encuentra en las jurisdicciones de derecho civil sobre la cuestión de la inmunidad-responsabilidad del árbitro no forma parte de la autoridad del derecho consuetudinario de los Estados Unidos sobre el tema. El esquema doctrinal de los Estados Unidos sobre la cuestión no tiene vestigios, tal vez en su detrimento, en una teoría contractual que sirva como base normativa para la inmunidad-responsabilidad del árbitro. La jurisprudencia sobre el tema se aferra al paradigma de la función judicial-resolutiva. Esta formulación, a su vez, ha conducido a un desarrollo doctrinal que proporciona una inmunidad absoluta a los árbitros indistinguible de la aplicable a los jueces, en relación con el desempeño de su función jurisdiccional judicial. Sin duda, este desarrollo conceptual y doctrinal encuentra su origen en el derecho consuetudinario inglés. Comprensiblemente, ha generado un considerable debate académico abordando los relativos méritos de lo que se ha identificado como una "sobreprotección." Esa preocupación invita a una revisión exhaustiva. Sin embargo, antes del examen de la cuestión, es necesario examinar los orígenes históricos de la inmunidad absoluta concedida a los árbitros.

\section{El rey no puede hacer nada mal: una palabra sobre la inmunidad judicial}

23. La palabra "absoluta" es desalentadora. La consistencia no calificada que no conoce excepción alguna es rara. Incluso lo que parecían ser verdades físicas absolutas como (i) la tasa de caída de los objetos, (ii) la relación orbital entre el sol y la tierra, y (iii) la posición relativa de la tierra con respecto al universo de los cuerpos celestes, mientras que una vez absoluto, eventualmente traspasó ese estatus a nuevas reglas que también reclamaban el manto de ser absolutas y libres de excepciones. Sin embargo, cada uno de estos tres ejemplos descansa en suposiciones no probadas que, con el paso del tiempo, ya sea por casualidad o diseño (en algunos casos ambos), no fueron sometidas a los efectos del razonamiento discursivo.

24. El componente "absoluto" de lo que eventualmente se convirtió en la doctrina de inmunidad del árbitro, de manera similar, tiene sus orígenes en un punto de partida casi divino, o eso se creía que era. Este curioso origen sigue siendo relevante. Por esta razón demanda atención.

25. El origen de la teoría de la inmunidad absoluta del árbitro es tan antiguo como la propia ley consuetudinaria. Sus raíces se remontan a la inmunidad judicial. El análisis de su fundamento normativo es aún más arcano y lineal en su desarrollo. La inmunidad judicial absoluta de derecho consue- 
tudinario, que los árbitros heredan más tarde, se basa en el principio semi religioso de la infalibilidad monárquica. $^{2}$

26. En la contribución clásica, Commentaries on the Laws of England, Blackstone argumenta con cada pedacito de la pasión de un monárquico que "[a]demás de los atributos de la soberanía, la ley también atribuye al rey, en su capacidad política, absoluta perfección." 3 Por lo tanto, el inmortal axioma de que "[e]1 rey no puede hacer nada mal."4 El principio es aún más amplio. Según Blackstone, "el rey, por otra parte, no sólo es incapaz de hacer nada mal, sino incluso pensar mal: nunca puede hacer una cosa inapropiada: en él no hay locura o debilidad. "5

27. Central a la doctrina monárquica de la infalibilidad de Blackstone es la calificación de que este estado de perfección se atribuye al rey por "la ley" y sólo se aplica al rey en "su capacidad política", y es sólo en ese estatus que él disfruta de "absoluta perfección." ${ }^{6}$ En este sentido, la infalibilidad del rey es, en cierto sentido, comparable a la calificación de infalibilidad de los pronunciamientos del Papa, según la cual el Papa es infalible sólo en cuanto a los asuntos de dogma y otras circunstancias calificadas. ${ }^{7}$ En consecuencia, la infalibilidad del rey está muy relacionada con su papel de soberano en la ejecución de la soberanía. Por lo demás, es imperfecto.

28. Esta distinción (soberano en la ejecución de la soberanía) importa más allá del valor de una mera premisa histórica. Aunque aparece como una cláusula subordinada aparentemente inocua en una frase espectacular, su influencia en la teoría del derecho consuetudinario de los Estados Unidos sobre la inmunidad absoluta del árbitro será primordial, aunque implícita. ${ }^{8}$

29. De hecho, representará el principio doctrinal con respecto al cual la teoría de la inmunidad absoluta del árbitro sería desafiada y tímidamente rendida a menos que absoluta. ${ }^{9}$

30. Ciertamente, la formulación de la infalibilidad monárquica de Blackstone no monopoliza en conjunto la formación y la transformación de la ley consuetudinaria, incluso con respecto a los supuestamente perfectos trabajos gubernamentales del rey. Dos razones parecen ser primordiales. Primero, el propio Blackstone luchó contra la disonancia entre la proposición que invoca la perfección, y el ejercicio menos que perfecto o sano de la soberanía por parte de la propia monarquía. Por lo tanto, su esfuerzo

2 Edwin M. Bouchard, Government Liability and Tort, 34 Yale LJ 1, 2 (1924 - 25); Edwin M. Bouchard, Government Liability and Tort, 34 YALE LJ 1, 17 - 41 (1926-27).

31 Sir William Blackstone, KNT., Commentaries On The Laws Of England In Four Books, With Notes Selected From The Editions Of Archibold, Christian, Coleridge, Chitty, Stewart, Kerr \& Others, Barron Field's Analysis And Additional Notes And A Life Of The Author, In Two Volumes - Books I \& II 246 (George Sharswood Ed., 1893).

${ }^{4} I d$. Este pasaje histórico en su totalidad dice:

El rey no puede hacer nada malo, máxima antigua y fundamental que no debe entenderse, como si todo lo que el gobierno transa es, por supuesto, justo y legal, sino significa sólo dos cosas. En primer lugar, que lo que sea excepcional en la conducción de los asuntos públicos, no debe ser imputado al soberano, ni tampoco éste es responsable personalmente ante su pueblo; por esta doctrina se destruiría totalmente esa independencia constitucional de la corona, que es necesaria para el equilibrio de poder en nuestra libre y activa, y por lo tanto amalgamada, Constitución. Y, en segundo lugar, significa que la prerrogativa de la corona no se extiende a ninguna lesión; se crea para el beneficio de la gente, y Id. por lo tanto no puede ser ejercida en su prejuicio.

${ }^{6} I d$.

${ }^{7}$ En 1870, Pío IX proclamó la doctrina de la infalibilidad papal con estas palabras "cuando el Romano Pontífice habla EX CATHEDRA, es decir, cuando, en el ejercicio de su oficio de pastor y maestro de todos los cristianos, en virtud de su suprema autoridad apostólica, define una doctrina sobre la fe o la moral que debe tener toda la iglesia, él posee, por la ayuda divina prometida a él en el Beato Pedro, esa infalibilidad que el Divino Redentor quiso que su iglesia disfrutara al definir la doctrina concerniente a la fe o la moral. Por lo tanto, tales definiciones del Romano Pontífice son en sí mismas, y no por el consentimiento de la iglesia, irreformables. " Primera constitución dogmática sobre la iglesia de Cristo Vaticano I, Sesión 4, 18 de julio de 1870 (cursiva agregada).

${ }^{8}$ Véase infra 9 ๆ 36 - 49.

${ }^{9}$ Véase Id. 
por cuadrar el círculo, postulando que incluso en los casos en que la realeza concede "cualquier franquicia o privilegio a un sujeto que contrario a la razón" resultase perjudicial para la comunidad, la ley presumirá que los terceros y no el rey deben ser considerados responsables. ${ }^{10}$ Aunque esta proposición lleva consigo el objetivo de la conveniencia política de preservar y perpetuar la monarquía, sus efectos prácticos sobre la mayoría de los temas no fueron particularmente acogidos.

31. En segundo lugar, al menos otro escritor influyente en el desarrollo y la transformación del derecho consuetudinario, que en realidad precedió a Blackstone, sostuvo una visión diametralmente opuesta de la cuestión. Henry de Bracton en su opus lapidario, De legibus ${ }^{11}$ desautorizó hábilmente el axioma de que "el rey no puede hacer mal" más por medio de sutiles analogías y metáforas entre la monarquía y lo divino, que de acuerdo con el razonamiento silogístico que puede haberle costado su vida en la Inglaterra del siglo XIII. Los paralelismos que se trazan entre "el bendito padre de Dios" y el rey como soberano son sutiles y algo engañosos. El argumento está dirigido a subordinar al rey a las leyes del hombre y, de este modo, situar al monarca equidistante cada sujeto respecto de las restricciones normativas de la ley. El texto merece cita:

El rey mismo, sin embargo, no debe estar bajo el hombre, sino bajo Dios, y bajo la ley, porque la ley hace al rey. Por lo tanto, que el rey regrese a la ley lo que la ley le da, es decir, el dominio y el poder; porque no hay rey donde la voluntad, y no la ley, empuña el dominio... Así también el bendito padre de Dios, la Virgen María, madre del Señor, que por un privilegio singular estaba por encima de la ley, por el bien de dar un ejemplo de humildad no retrocedió a seguir ordenanzas legales. El rey debe actuar del mismo modo, no sea que su poder permanezca desenfrenado. ${ }^{12}$

32. Aunque la visión contemporánea es que muchas manos jugaron un papel en la autoría de $D e$ legibus ${ }^{13}$ no hay discusión alguna sobre que Bracton es responsable de favorecer el estado de derecho como el principio normativo principal, más destacado y de mayor autoridad de la monarquía. Además de las elegantes metáforas y símiles a "los bienaventurados padres de Dios", identificar a "la ley" como el fundamento y origen de la autoridad rey, en lugar del derecho divino, no debe pasarse por alto ni ser desechado.

33. El giro doctrinal cambiante del péndulo es severo. La identificación de la ley hecha por el hombre como la fuente normativa fundacional de la autoridad del monarca, pronto desafió el axioma de Bracton, y más tarde el de Blackstone, más enfático de que "el rey no puede hacer mal." ${ }^{14}$ El axioma públicamente se identificó en algunos sectores, de forma burlona, como una "perversión ridícula." ${ }^{15}$ Además se ha señalado que la historia establece de manera convincente que "el rey no sólo es capaz de hacer el mal, sino que es probable que haga más el mal que cualquier otro hombre si se le da la oportunidad."16

\footnotetext{
${ }^{10}$ Véase supra 9 甲 25 - 27.

${ }^{11}$ Henry de Bracton, Bracton De Legibus y Consuetudinibus Anglice ("De legibus") (George E. Woodbine Ed., Yale University Press 1922).

${ }^{12}$ Bracton De Legibus III, 0.2 - 1,56 (citado en John c. h. Wu, Fountain of Justice: A Study in the Natural Law 71 n.85, 73 (1955) (énfasis en original).

Se debe observar que Henry de Bracton erróneamente ha sido llamado "el padre del derecho consuetudinario." Véase, por ejemplo., Noel P. Fox, The King Must Do No Wrong: A Critique of the Current Status of Sovereign and Official Immunity, 25 Wayne L. Rev. 193 (1979). Este error es una republicación de un, poco relacionado pero diferente, título atribuido a Bracton. 1 Canciller James Kent, Commentaries on American Law 499 (O. W. Holmes, JR. ED., 12Th ed., 1873) a/k/a "Comentarios de Kent", se refirió a Bracton como "El Padre de la Ley Inglesa."

El título "Padre del Derecho Consuetudinario" se ha otorgado más apropiadamente al rey Enrique II, bisnieto de Guillermo el conquistador, e hijo de Matilda, hija del segundo matrimonio de Enrique I de Inglaterra con Geoffrey de Anjou.

${ }^{13}$ Véase Morris S. Arnold, Book Review. De Legibus et Consuetudinibus Angliae, 91 Harv. L. Rev. 517, 518 (1997) (afirmando que "el profesor Thorne demuestra que el libro de notas de Bracton (se ha llamado así desde hace casi 100 años) no tiene relación alguna con el Tratado. Aún más sorprendente, parece que Bracton no escribió la mayor parte del De Legibus".).

${ }^{14}$ Supra $\uparrow \uparrow 25-31$.

${ }^{15}$ Fox, supra n. 13 (citado por Wu, supra n. 13, en 71, 161 n. 85).

${ }^{16}$ Id. (citando a A.P. Herbert, UnCOMMON $292-93$ (1935).
} 
34. Bracton precedió a Blackstone por quinientos ochenta años. En el momento en que Blackstone estaba escribiendo disculpas y comentarios sobre la infalibilidad del rey, y ciertamente para 1688, el absolutismo real que los Stewarts reclamaron fue sustituido por el absolutismo parlamentario. La abstracción más general de la infalibilidad del rey es, en efecto, la inmunidad soberana. El axioma "[e] n tiempos modernos, se explica más a menudo como una regla de la política social, que protege al Estado contra la interferencia gravosa en el desempeño de sus funciones gubernamentales y preserva su control sobre los fondos, la propiedad y los instrumentos estatales. La inmunidad se extiende también a los funcionarios y agencias del Estado que se dedican a llevar a cabo sus funciones gubernamentales, y una demanda contra dicho funcionario o agencia se considera como una contra el propio Estado. " (citas omitidas) ${ }^{17}$ Comprensiblemente, la inmunidad que protege al rey fue transmitida a todos los representantes de la corona, en el ejercicio de la soberanía regulatoria, administrativa, real o legislativa. Por supuesto, en esta categoría estaban principalmente los jueces.

35. De hecho, antes de la adopción de la ley de arbitraje 1996, el Reino Unido concedió una inmunidad prácticamente absoluta a los árbitros, y mucho más a los jueces. ${ }^{18}$ La ley inglesa se mantuvo como un parangón judicial ${ }^{19}$ y la inmunidad absoluta del árbitro antes de la aprobación de la ley de arbitraje de $1996,{ }^{20}$ pese a la naturaleza absoluta de la inmunidad soberana, que los Estados Unidos disfrutaron hasta 1976 con la aprobación de la ley de inmunidad soberana extranjera, ${ }^{21}$ es significativamente menos clara. ${ }^{22}$ El derecho consuetudinario inglés dio lugar al derecho consuetudinario de los Estados

${ }_{17}$ Glassman v. Glassman, 309 N.Y. 436, 440 (1956) (citando a Estados Unidos v. Lee, 106 U.S. 196, 206 (1882)); Véase también Joseph D. Block, Suits Against Public Officers and the Sovereign Immunity Doctrine, 59 Harv. L. Rev. 1060, 1061 (1946); Pstay v. Duryea, 306 N.Y. 413 (1954); Breen v. Mortgage COMM., 285 N.Y. 425, 429 - 30 (1941); Volk v. Nueva York, 284 N.Y. 279, $285-87$ (1940).

${ }^{18}$ La ley de arbitraje del Reino Unido. 29 (1996) en la parte pertinente dice:

29 inmunidad del árbitro

(1) Un árbitro no es responsable de nada hecho u omitido en el desempeño o supuesto desempeño de sus funciones como árbitro, a menos se demuestre que el acto u omisión que ha sido de mala fe.

(2) la subsección (1) se aplica a un empleado o agente de un árbitro, como se aplica al propio árbitro.

(3) esta sección no afecta a ninguna responsabilidad en la que haya incurrido un árbitro en razón de su renuncia (ver sección 25).

En aras de la exhaustividad, la sección 25 establece:

Renuncia del árbitro.

(1) Las partes son libres de acordar con un árbitro en cuanto a las consecuencias de su renuncia en lo que respecta a-

(a) su derecho (si lo hubiera) a honorarios o gastos, y

(b) cualquier responsabilidad incurrida por él.

(2) Si, o en la medida en que no exista tal acuerdo, se aplicarán las siguientes disposiciones.

(a) para hacer el pedido que considere adecuado con respecto a su derecho (si lo hubiera) a honorarios o gastos o al reembolso de cualquier cargo o gasto ya pagado.

(3) Un árbitro que renuncia a su nombramiento puede (previa notificación a las partes) aplicar a la corte -

(a) Para que le conceda alivio de cualquier responsabilidad, ya sea incurrida por él, y

(4) Si el Tribunal está convencido de que, en todas las circunstancias, era razonable que el árbitro renunciara, puede otorgar tal alivio, como se menciona en el inciso (3) (a) en los términos que considere aptos.

(5) La licencia del Tribunal se requiere para cualquier apelación de una decisión del Tribunal bajo esta sección.

Véase también Varapnickas, Tadas Varapnickas, Issues of Arbitrator's Liability as Regards the Right to Fair Trial: What

Way to Choose for Policy-Makers, 20 VJ 95, 103 (2016; Emmanuela Truli, Liability v. Quasi-Judicial Immunity of the Arbitrator: A Case Against Absolute Immunity, 17 AM. Rev. InT'L ARB. 7 (2006).

${ }^{19}$ Bremer Vulkan v. South India Shipping (H.L.), [1981], AC $909-21$.

${ }^{20}$ En Bremer Vulkan v. South India Shipping (H.L.) Donaldson, J. afirmó que "los tribunales y árbitros están en el mismo negocio, a saber, la administración de la justicia." Bremer Vulkan v. South India Shipping (H.L.), [1981], AC 909 - 21.

${ }^{21} 28$ U.S.C. $\S \S 1330,1332,1391$ (f), 1441 (d), y $1602-11$.

${ }^{22}$ Históricamente, el derecho inglés parece haber sido más permisivo en la cuestión de la inmunidad soberana en general. Sobre este tema, Joseph Story observó:

Ha pasado algún tiempo pensándose que esta [posible indemnización para el ciudadano estadounidense por el gobierno de los Estados Unidos] es un grave defecto en la organización del Departamento Judicial del gobierno nacional... En este sentido, existe un marcado contraste entre los reales derechos y la práctica de la indemnización en el gobierno nacional, así como entre la mayoría de los gobiernos estatales y el derecho y la práctica mantenidos bajo la Constitución británica. En Inglaterra, si alguna persona tiene, en un asunto de propiedad, una demanda justa sobre el rey, puede pedirle en su corte de chancery, lo que se llama una petición de derecho,) donde el canciller administrará 
Unidos sobre la inmunidad judicial. Es aquí donde la expresión más expansiva de la inmunidad absoluta del árbitro se ha desarrollado y sigue influyendo en el contenido doctrinal del derecho consuetudinario de los Estados Unidos.

\section{La inmunidad judicial dio lugar a la inmunidad del árbitro: un paradigma falso}

36. Los tribunales estadounidenses no han sido tímidos al desarrollo doctrinal inglés proporcionando a los jueces una inmunidad absoluta. ${ }^{23}$ El juez Kent en Yates v. Lansing, presidió un caso de la Corte Suprema de Nueva York de $1810^{24}$ sobre un recurso hábeas corpus interpuesto por un acusado que, después de haber sido liberado, fue re convicto con base en el supuesto daño que le había causado ser detenido, y posteriormente liberado, en primera instancia. El detenido del hábeas corpus después de haber sido re convicto e "injustamente e ilegalmente encarcelado por el Sheriff de Albany" durante dos días, de conformidad con una orden injusta derivada de un tribunal carente de jurisdicción, presentó una reclamación contra el Canciller de Nueva York, John Lansing, quien "a sabiendas, injustamente, y contrariamente a la ley [en cuestión] hizo que el demandante fuera re convicto y encarcelado por el mismo delito establecido en el mandamiento auxiliar inicial. "25 El estatuto específico sobre el que se basó la acción contra la Cancillería disponía:

Ninguna persona, en general, bajo cualquier hábeas corpus, será encarcelada de nuevo por el mismo delito, salvo por una orden legal o el procedimiento de la corte a la que está obligado a comparecer, $\mathrm{u}$ otro tribunal que tenga jurisdicción sobre la causa; y si alguna persona, a sabiendas, contrariando a esta norma, vuelve a enjuiciar o encarcelar, o arresta o encarcela a cualquier persona por el mismo delito, pagará a la parte afligida, $\$ 1.250 .{ }^{26}$

37. Al señalar que "[de] acuerdo al juicio del Tribunal, no puede haber un pretexto para esta demanda, incluso si el demandado fue de otra manera responsable de un ejercicio indebido o de una incorrecta aplicación de las facultades de su corte," el Canciller Kent pensó en explorar desechar las reclamaciones por otros motivos, y observó específicamente que "el punto que ahora quiero considerar principalmente es, si puede haber algún fundamento en la ley para la demanda, admitiendo que el demandado se equivocó al suponer que el descargo del demandante bajo el Hábeas Corpus, se hizo indebidamente. "27 Al responder a la pregunta negativa, el Canciller Kent se basó en el precedente del derecho consuetudinario inglés.

38. Concretamente, se observó que la doctrina que responsabiliza a los jueces en caso de una intrusión excediendo su jurisdicción y de un procedimiento coram non judice no encontraba precedente vinculante de ningún tipo. En cuanto a este precepto, el tribunal afirmó que la "doctrina ${ }^{28}$ nunca ha

derecho, teóricamente, como una cuestión de gracia, y no bajo compulsión: pero, de hecho, como una cuestión de deber constitucional. Ningún procedimiento judicial de este tipo se reconoce como existente en ningún estado de esta Unión, como una cuestión de derecho constitucional, para hacer valer cualquier reclamo o deuda contra un Estado . . .. Sin duda puede constituir una fuente desagradable de reflexión para un ciudadano estadounidense, orgulloso de sus derechos y privilegios, que en una monarquía el poder judicial esté revestido con amplios poderes para dar reparación al sujeto más humilde en una cuestión de un contrato privado o de propiedad contra la corona y que en una República haya, en tales casos, una denegación absoluta de justicia a cualquier ciudadano a través de la instrumentalidad de cualquier proceso judicial.

Joseph Story, Commentaries on the Constitution of the United States sec. 1672 (1833), en John Devereux, Reports and Digest of Opinions, U.S. Court of Claims at appendix pp. 43-44 (1856). Véase también, John E. SHERry, The Myth That the King Can Do No Wrong: A Comparative Study of the Sovereign Immunity Doctrine in the United States and New York Court of Claims, 22 Admin. L. Rev. 39, 41 n.13 (1969).

${ }^{23}$ Véase supra $\uparrow \uparrow 14-22$.

${ }^{24}$ J.V.N. Yates v. Lansing, 5 Johns. 282 (NY sup. CT. 1810).

${ }^{25} I d$.

${ }^{26} I d$. en 288.

${ }^{27} I d$.

${ }^{28} I d$. 
llevado a justificar una demanda contra los miembros de los tribunales superiores con jurisdicción general por cualquier acto realizado por ellos en capacidad judicial. No existe tal caso o decisión que [el Tribunal] [se haya] reunido, y [el Tribunal] encuentra que la doctrina es decididamente de otra manera."

39. Citando a Lord Ch. J. De Grey en Miller v. Seeve ${ }^{29}$ el Tribunal razonó que "los jueces de los tribunales superiores del rey con jurisdicción general no estaban obligados a responder personalmente por sus errores de juicio. La protección para ellos era

40. absoluta y universal; con respecto a tribunales inferiores, sólo cuando actúan dentro de su jurisdicción."(énfasis añadido) El análisis distinguió además entre los jueces "solo actuando ministerial o extrajudicialmente fuera de la corte" y los actos "de un tribunal hechos en el expediente."

41. El Canciller Kent entendió la queja como un pretexto para explorar la historia de la jurisprudencia del derecho consuetudinario inglés que aborda la inmunidad judicial, sus elementos, el alcance de su aplicación respecto a los "tribunales superiores con jurisdicción general" y a los "tribunales inferiores", y las consecuencias en las políticas públicas de interpretar la legislación que establece una causa de acción contra los funcionarios judiciales como inaplicable a reales adjudicadores, con base en un principio más alto de la construcción estatutaria que proscribe una interpretación que violentaría al sistema judicial en su conjunto. ${ }^{31}$ El Canciller Kent identifica la inmunidad judicial como una piedra angular de la jurisprudencia inglesa. Además, lo describe como el principio que se ha mantenido constante, a pesar de los continuos cambios que forman parte de un sistema orgánico de derecho consuetudinario, y considera necesario revisar la larga y distinguida historia de la doctrina en el marco del derecho consuetudinario inglés:

La doctrina que mantiene a un juez exento de una demanda civil o de una acusación, por cualquier acto hecho u omitido por él, ejerciendo como juez, tiene una profunda raíz en el derecho consuetudinario. Se encuentra en los primeros registros judiciales, y ha sido mantenido constantemente por una corriente no perturbada de decisiones en las cortes inglesas, en el medio de cada cambio de política, y a través de cada revolución de su gobierno. Una breve visión de los casos nos enseñará a admirar la sabiduría de nuestros antepasados y a venerar un principio sobre el cual descansa la independencia de la administración de justicia. Juvat accedere fontes atque haurire. ${ }^{32}$

42. Yates v. Lansing, decidida en 1810 , sigue siendo de importancia tanto teórica como práctica y, por lo tanto, esencial para la academia sobre el tema por dos razones principales. En primer lugar, sirve como un documento histórico que narra el derecho inglés sobre el tema. A este respecto, supera con creces un mero catálogo de decisiones. En cambio, el Canciller Kent, tanto como un erudito como un jurista, selecciona de un tesoro de autoridad los casos más emblemáticos. Por lo tanto, no es de extrañar que Lord Ch. J. Wilmot y Lord Coke sean destacados de manera prominente.

${ }^{29}$ Miller v. Seeve (2 Black. Rep. 1141) citado en J.V.N. Yates V. Lansing, 5 Johns. 282 (NY Sup. CT. 1810).

${ }^{30} \mathrm{Id}$.

${ }^{31}$ En cuanto a este punto, el Tribunal razonó:

La ley permite que la parte así liberada, sea encarcelada de nuevo por el mismo delito, siempre que sea por orden legal o el proceso de la Corte a la que está obligada por el reconocimiento a comparecer, $u$ otro tribunal que tenga jurisdicción sobre la causa. Cualquier tribunal que tenga jurisdicción sobre el tema, puede reencarcelar, a pesar de la liberación. Para indicar un caso sencillo; Si una persona acusada en un tribunal Oyer and Terminer, o de Paz de un delito grave, y encarcelada en una prisión estatal, es liberada por un juez en hábeas corpus, sobre la base de que el Tribunal no tenía autoridad para encarcelar, o que la orden de encarcelamiento no era válida, ¿dudaría alguien que el Tribunal podría hacer que el convicto sea reencarcelado, ya sea por la misma orden, si la juzgó suficiente, o mediante la adjudicación de una nueva y mejor orden? el estatuto nunca pretendió tal destrucción de principios, como confiar a un juez en receso, el poder de controlar la sentencia, o comprobar la jurisdicción de un tribunal de registro.

(cursiva agregada).

${ }^{32}$ El Canciller Kent para el reenvío de la opinión procede a resumir no menos de diez casos que comienzan con la identificación del principio tan tempranos como El libro de Asís, 27 Ed. III, p.l. 18 que data de 1354. 
43. Segundo Yates v. Lansing acentúa la doctrina y no sólo la articula. Especial cuidado y consideración es otorgada a la presentación de la doctrina como internamente fundacional al marco de referencia de la jurisprudencia y externamente a la relación de la doctrina con la integridad estructural del sistema judicial. Con todas las triquiñuelas del romanticismo de principios del siglo XIX, las líneas finales de la opinión apuntan a esta proposición:

Ningún hombre puede prever las consecuencias desastrosas de un precedente a favor de semejante traje. Siempre que sometamos a los tribunales establecidos de la tierra a la degradación del enjuiciamiento privado, sometemos su independencia y destruimos su autoridad. En lugar de ser venerables ante el público, se vuelven despreciables; y así envalentonamos a los licenciosos a pisotear todo lo sagrado en la sociedad, y a darle la espalda a las instituciones que, hasta ahora, han sido consideradas las mejores guardianas de la libertad civil.

44. La naturaleza absoluta de la inmunidad articulada en Yates v. Lansing, efectivamente, requieren cierta cualificación. El "Scinter" o "violación intencional de la ley", en cierta medida, perforaría la inmunidad. Sin embargo, en el caso de un juez, aún tal alegato no daría lugar a una causa privada de acción, sino más bien a un procedimiento de destitución. La creación de esta excepción se reiteró apenas cuatro años después de la emisión de la decisión Yates v. Lansing, en virtud de una configuración fáctica que encarnaba la edad oscura de la preguerra civil americana.

45. En Jenkins, et al. v. Waldron ${ }^{33}$ la Corte Suprema de Justicia de Nueva York ejerció certiorari de jurisdicción para revisar una sentencia a favor del demandante por "\$3 de daños y los costos." ${ }^{14}$ En ese caso, la corte describió al demandante como "un hombre negro o de color; y que en el momento en que ofreció el voto presentó un certificado de ser un hombre libre, bajo la mano y el sello de Samuel Edmonds, uno de los jueces de la Corte de Súplicas Comunes del Condado de Columbia, fechado 9 Abril 1811, certificado que fue registrado en la oficina del secretario de la ciudad de Livingston, y cuya copia fue certificada por el secretario de la ciudad. "35

46. En pocas pocas, el demandante demandó a los inspectores electorales porque le negaron su derecho a votar, con base en el pretexto insostenible de que al momento de haberse convertido en "un hombre libre" Samuel Edmonds no era juez. Los inspectores de votación que se consideraba que actuaban en una capacidad cuasi judicial, apelaron alegando inmunidad.

47. El expediente en apelación reflejaba que "el demandante había, durante 8 o 10 años previos a la elección de 1811, votado por miembros de la asamblea, $y$ en algunas de las elecciones durante ese periodo, algunos de los demandados eran inspectores de la votación y recibieron el voto del demandante." ${ }^{36}$ (énfasis Añadido) A pesar del predicado fáctico de este caso, que habría justificado que se desestimara sumariamente la apelación, los jueces sostuvieron notablemente "que no había pruebas, que se hubieran dado en el juicio, para demostrar que los acusados, al rechazar el voto del demandante, actuaron por motivos corruptos o maliciosos hacia el demandante, o por cualquier otro deseo o voluntad que cumplir sus deberes como inspectores". Por otra parte, el juez Spencer, que emitió la opinión de la Corte, observó además que si el magistrado Edmonds era un juez activo en el momento en que el demandante recibió un certificado de libertad no era relevante porque "no se alegó ni demostró que los inspectores fraudulenta o maliciosamente se negaron a recibir el voto de Waldron; y esto consideramos que es absolutamente necesario para el mantenimiento de una acción contra los inspectores de una elección." ${ }^{37}$

\footnotetext{
33 Jenkins v. Waldron, 11 Johns. 114 (NY Sup. CT. 1814).

${ }^{34} \mathrm{Id}$. en 116.

${ }^{35}$ Id. en 114.

${ }^{36} I d$. en 115.

${ }^{37} I d$. en 119 (cursiva agregada, énfasis en original).
} 
48. La excepción a la inmunidad de Yates v. Lansing, que fue extraída del derecho consuetudinario inglés, encontró su camino a la opinión de Jenkins, et al. v. Waldron. La anomalía que impregna el razonamiento del juez Spencer difícilmente podría ser más clara. La inobservancia por el Tribunal de las constataciones fácticas materiales del expediente sencillamente no puede conciliarse. No se pueden explicar. La decisión equivale a una afirmación que una persona razonable estaría proscrita de inferir de la premisa de que "el demandante había, durante los 8 o 10 años previos a la elección en 1811 [la elección que dio lugar a esta acción] votado por los miembros de la Asamblea, y en algunas de las elecciones durante ese período, algunos de los acusados fueron inspectores de la votación y recibieron el voto del demandante", los inspectores actuaron sobre la base de "motivos maliciosos "o de la institucionalización "corrupta" de la discriminación racial. El uso del Scinter del derecho consuetudinario inglés o el "motivo malicioso" excepción a la inmunidad es nada alejado de moralmente indefendible. ${ }^{38}$ Enmarcar la supuesta insuficiencia técnica como un defecto de la solicitud o de las pruebas, simplemente constituye la naturaleza de los lentes racistas a través de los cuales el juez Spencer pronunció la opinión del Tribunal.

49. Incluso en sus orígenes embrionarios el derecho consuetudinario de los Estados Unidos, la protección judicial, de la que se deriva la inmunidad absoluta del árbitro, ofrecía menos indicios sutiles de que la sobreprotección podía convertirse en un problema significativo que asegurando desarrollo doctrinal.

\section{La Corte Suprema de Estados Unidos aborda la Inmunidad Judicial: El magistrado Stephen J. Field y los Casos Emblemáticos Randall v. Brigham y Bradley v. Fisher}

50. En Randall v. Brigham ${ }^{39}$ el recurrente apeló a la Corte Suprema de Estados Unidos el rechazo por un tribunal de circuito de una queja presentada contra un juez en las cámaras de la Corte Superior de Massachusetts, un tribunal con jurisdicción general, alegando una denegación indebida, con base en la ausencia de debido proceso bajo la Constitución de Massachusetts. El juez Field emitió la opinión del Tribunal confirmando el rechazo de la Corte de circuito por dos razones. En primer lugar, en parte, con base en el apoyo analítico de Yates v. Lansing, la Corte, en un único párrafo, resumió 400 años de jurisprudencia sobre la cuestión de la inmunidad judicial:

Ahora bien, es un principio general aplicable a todos los funcionarios judiciales, que no son responsables de una acción civil por cualquier acto judicial hecho dentro de su jurisdicción. En referencia a los jueces de autoridad limitada e inferior, se ha declarado que sólo están protegidos cuando actúan dentro de su jurisdicción, si este es el caso con respecto a ellos, no existe tal limitación con respecto a los jueces de autoridad superior o general. Éstos no son responsables de acciones civiles por sus actos judiciales, incluso cuando tales actos superan su jurisdicción, a menos, tal vez, que los actos, en exceso de jurisdicción, se hagan maliciosa o corruptamente. Esta doctrina es tan antigua como el derecho, y su mantenimiento es esencial para la administración imparcial de la justicia. Cualquier otra doctrina conduciría necesariamente a la degradación de la autoridad judicial y a la destrucción de su utilidad. A menos que los jueces, en la administración de la justicia, no estén influenciados por consideraciones personales sobre sí mismos, podrían brindar poca protección al ciudadano sobre su persona o propiedad. Y sin la influencia de tales consideraciones, no pueden, cada vez que se equivoquen en el juicio sobre su jurisdicción, cuya naturaleza y alcance están constantemente obligados a aprobar, ser sometidos a enjuiciamiento a instancias de cada parte que se imagina a sí misma afligida, y ser llamados a una acción civil en otro tribunal, y tal vez ante un juez inferior, para reivindicar sus actos.

51. Esta completa iteración de la doctrina contiene las calificaciones estándar relativas a los "jueces de autoridad superior o general" y a los "jueces de autoridad limitada e inferior", con respecto a "cualquier acto judicial que se haga dentro de su jurisdicción."

\footnotetext{
${ }^{38}$ Id. $115-16$.

${ }^{39}$ Randall v. Brigham, 74 U.S. 523 (1869).
} 
52. El desarrollo más sutil se refiere a las palabras "a menos tal vez" calificando el componente Scinter "maliciosa o corruptamente" de la excepción. La doctrina, según lo articulado por el juez Field en Randall v. Brigham, parece albergar una ambigüedad intencional que puede, a capricho de la discreción judicial, eviscerar por completo la excepción. Por lo tanto, el alcance casi absoluto de la doctrina comenzó a madurar a partir de esta opinión. La afirmación, sin más, de una formulación tan autoritaria, robusta e integral de la doctrina, habría sido suficiente para confirmar la sentencia de. Sin embargo, la Corte consideró que la Corte de Circuito había, en efecto, sido provista de una demanda suficientemente formal contra él como para dar lugar al ejercicio adecuado de su competencia sobre la causa. Por lo tanto, la afirmación del apelante relativa a la privación de derechos en virtud de la Constitución de Massachusetts careció de mérito y justificó una confirmación de la orden por la Corte Superior de Massachusetts.

\section{EI Efecto de la Reconstrucción de la Guerra Civil en el Desarrollo de la Doctrina}

53. Randall v. Brigham, necesita ser contextualizada. La opinión fue emitida en 1869, apenas tres años después la promulgación de la ley de derechos civiles de 1866, y sólo dos años antes la promulgación de la ley de derechos civiles de $1871 .^{40}$ Más importante aún, esta época de reconstrucción posterior a la guerra civil marcó un período de cambio e incertidumbre. Algunos de los pilares más fundacionales de una joven República, en realidad fundada en un modelo económico con base en la esclavitud, habían sido desalojados y difícilmente reemplazados como una cuestión de derecho, cultura, práctica y relaciones rudimentarias de raza. Gran parte de este cambio recayó sobre la Corte. Los efectos fueron consecuentes y no pueden ser extraídos de casos que aparentemente podrían potencialmente abordar la solidez de la integridad institucional y la seguridad. Las Cortes no fueron una excepción.

54. La incertidumbre que rodeaba y realmente engulló la reconstrucción generó preguntas básicas a las que la Corte se volvería, dedicando todo su tiempo y la energía, con la que todavía las enfrenta hasta el día de hoy. ¿Cómo reaccionará el sistema estadounidense de gobierno y sus tribunales a la abolición de la esclavitud? ¿Cómo se reconstruirá la economía y su fuerza de trabajo? Específicamente, ¿qué sistema o sistemas de mano de obra reemplazarían a la mano de obra esclava? ¿Cómo se

${ }^{40}$ Ley de 20 de abril de 1871 Ch. 22, Sección, 17 stat. 13, también conocida como La cuarta ley de 1871, o la ley Ku Klux Klan.

Esta legislación fue la predecesora original de la actual iteración de 42 U.S.C. § 1983 ("acción civil por privación de derechos"). La predecesora de 1871 representó el último de los tres actos de observancia que el Gobierno Federal aprobó durante la era de reconstrucción de 1870 - 71. La legislación original, tal como se promulgó en 1871, dice:

Que cualquier persona que, bajo una legalidad aparente viole cualquier ley, estatuto, ordenanza, reglamento costumbre o uso del Estado, será responsable ante la parte lesionada en cualquier acción en derecho, demanda en equidad, $\mathrm{u}$ otro procedimiento apropiado para la reparación; tales procedimientos, en los distintos tribunales de distrito o de circuito de los Estados Unidos, estarán sujetos a los mismos derechos de apelación, revisión por error, y otros recursos previstos para casos semejantes en tales tribunales, de conformidad con las disposiciones de la [Ley de derechos civiles de 1866], y las demás leyes correctoras de los Estados Unidos que sean en su naturaleza aplicables en tales casos.

Esta legislación fue modificada en dos ocasiones adicionales: 1979-pub. L. 96-170 insertado "o el Distrito de Columbia" después de "territorio", y las disposiciones relativas a los actos del Congreso aplicables únicamente al Distrito de Columbia.

En 1996-pub. L. 104-317 la enmienda introducida antes del punto al final de la primera frase, "salvo en cualquier acción entablada contra un funcionario judicial por un acto u omisión adoptado en la capacidad judicial de dicho funcionario, que no se concederá una medida cautelar a menos que un decreto declaratorio fuese violado o el alivio declaratorio no estuviere disponible". En consecuencia, la iteración actual del 42 U.S.C. § 1983- La acción civil por privación de derechos establece que:

Cada persona que, bajo una legalidad aparente viole cualquier estatuto, ordenanza, regulación, costumbre o uso, de cualquier Estado o territorio o del distrito de Columbia, someta o cause que sea sometido cualquier ciudadano de los Estados Unidos o persona dentro de la jurisdicción del mismo a la privación de cualesquiera derechos, privilegios o inmunidades garantizados por la Constitución y las leyes, será responsable ante la parte lesionada bajo una acción judicial, demanda en equidad u otro procedimiento apropiado de reparación, excepto en cualquier acción entablada contra un funcionario judicial por un acto u omisión tomado en la capacidad judicial de dicho funcionario, donde no se concederá una medida cautelar a menos que se viole un decreto declaratorio o se haya incumplido el alivio declarativo. Para los fines de esta sección, se considerará que una ley del Congreso aplicable exclusivamente al Distrito de Columbia es un estatuto de ese Distrito. 
transformarían las relaciones de raza de la esclavitud y de conformidad con cuáles modelos legales y éticos? ¿Los esclavos libres se convertirán automáticamente en ciudadanos estadounidenses, y todos los ciudadanos tendrían derecho a idénticos derechos? ¿Cuáles desafíos constitucionales derivarían de los "nuevos" paradigmas de "ciudadanía"? La naturaleza tan básica de estas pocas preguntas multiplicó exponencialmente la incertidumbre legislativa y judicial de aquellos tiempos ${ }^{41}$ La pequeña maravilla de la inmunidad judicial tuvo que volverse absoluta.

55. Añada a esta incertidumbre la naturaleza muy embrionaria de la Corte, de la que el juez jefe Field era sólo uno de los cuatro demócratas del norte en el Tribunal. Además, el juez Field entregó las opiniones en Randall v. Brigham ${ }^{42}$ y Bradley v. Fisher ${ }^{43}$ al comienzo de una nueva era en la historia de la Corte. Sólo los jueces Samuel Nelson y Robert Grier se habían sentado en la Corte durante más de un puñado de años con el jefe de justicia Roger Taney, y habrían de permanecer en el tribunal por un período de tiempo significativo. Entre 1858 y 1864 seis nuevos miembros serían nombrados para servir con los jueces Nelson y Grier. Cinco de ellos fueron designados por Lincoln y cuatro eran republicanos: Nathan Clifford, Noah J. Swayne, Samuel F. Miller, David Davis, Stephen J. Field, y el propio jefe de justicia Chase. De hecho, hasta la muerte de Chase en 1873, estos jueces servirían juntos. ${ }^{44}$ Así, en el momento en que el juez Field emitió la opinión en Randall v. Brigham ${ }^{45}$ había desempeñado un papel clave en tres casos transformadores, entregando la opinión de la Corte en dos de ellos.

56. La incertidumbre causada por la reconstrucción inspiró en el juez Field la necesidad de fortalecer y envalentonar la credibilidad normativa de la Corte y el compromiso inquebrantable del poder judicial con el Estado de Derecho. En consecuencia, es comprensible que en este clima de cambio y falta de valor predictivo, el juez Field encontrara no sólo convincente, sino realmente necesario, proporcionar al poder judicial una inmunidad prácticamente sin calificaciones. La tarea de interpretar las "Enmiendas de la Guerra Civil" invitaría a desafíos a la credibilidad judicial y a la legitimidad normativa, provenientes de los estados del sur, el Congreso, los detractores políticos en desacuerdo con la reconstrucción en general, y un número significativo de jueces de tribunales federales y estatales. En consecuencia, en el momento en que Bradley v. Fisher se adjudicó (1872) la Corte había comenzado ya a dedicar casi todo su tiempo y energía a la interpretación de las enmiendas decimotercera y decimo-

${ }^{41}$ Véase ERIC Froner, The Supreme Court and the History of Reconstruction - And Vice-Versa, 112 Colum. L. Rev. 1585, 1587 (2012).

${ }^{42}$ Randall v. Brigham, 74 U.S. 523 (1869).

${ }^{43}$ Bradley v. Fisher, 80 U.S. 335 (1871).

${ }^{44}$ Véase David P. Currie, The Constitution in the Supreme Court: Civil War and Reconstruction, 1865-1873, 51 U. CHI. L. Rev. 131, 137 - 138 n. 1, citando un cuadro de la página 132 adaptado de G. Gunther, From G. Gunther, Cases and Materials on Constitutional Law, en a-2 a a-4 (10 Ed. 1980), aquí reproducido:

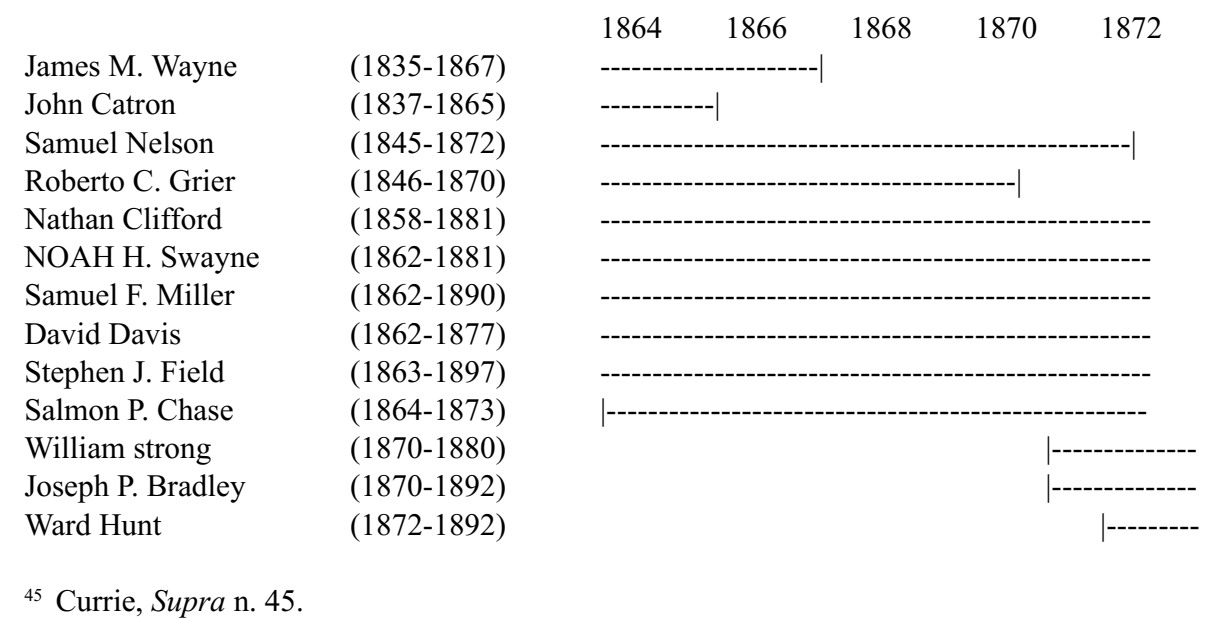


cuarta. El papel protagónico del juez Field en Ex Parte Milligan ${ }^{46}$ Cummings v. Missouri, ${ }^{47}$ y Ex Parte Garland $^{48}$ (los casos de juramento de prueba) es conceptualmente, y no simplemente históricamente, gran parte del desarrollo de la doctrina de la inmunidad judicial que anunció al hablaba por la Corte en Randall v. Brigham y Bradley v. Fisher.

57. Los cuatro demócratas del norte, Field, Nelson, Grier y Clifford se unieron a la opinión de Davis en Ex Parte Milligan, porque Ex Parte Milligan se decidió sólo tres años antes de que el juez Field entregara la opinión del Tribunal en Randall v. Brigham, así como en Ex Parte Milligan resuena el elogio al Estado de Derecho, es importante volver a visitar el caso para contextualizar mejor a Randall v. Brigham, y antes de estudiar a Bradley v. Fisher.

\section{Ex parte Milligan}

58. El 5 de octubre de 1864, mientras estaba en su hogar en Indiana, la vida de Lambdin P. Milligan cambiaría para siempre. En esa fecha fue arrestado en su casa de conformidad con una orden que el general Alvin P. Hovey, al mando del distrito militar de Indiana, había emitido. ${ }^{49}$ Poco más de dos semanas después de su arresto, el 21 de octubre, Milligan "fue llevado ante una Comisión Militar convocada en Indianápolis, por orden del general Hovey, con ciertos cargos y especificaciones; encontrado culpable, y sentenciado a ser ahorcado; y la sentencia ordenó que se le ejecutara el viernes, 19 de mayo 1865." 50

59. Sólo nueve días antes del 9 de mayo de 1865, día de la ejecución, Milligan apeló al Tribunal de Circuito del Distrito de Indiana de los Estados Unidos para que fuera liberado de lo que alegaba era un encarcelamiento ilegal. ${ }^{51}$

60. Su argumento era simple y persuasivo. Milligan era un ciudadano estadounidense que vivió durante veinte años en el estado de Indiana. Lo más importante, sin embargo, es que en el momento de las acusaciones en cuestión no estaba, y nunca había estado, en las fuerzas armadas de los Estados Unidos. ${ }^{52}$ Por lo tanto, bajo ningún análisis, un tribunal militar tenía autoridad para enjuiciar a un ciudadano civil de los Estados Unidos por cualquier supuesta mala conducta, y mucho menos condenar y sentenciar a un civil a muerte por ahorcamiento. Milligan también insistió en que la comisión militar era ilegal porque violaba su derecho constitucional a un juicio por jurado. ${ }^{53}$

61. El Tribunal enmarcó "[1]a pregunta de control" de manera concisa y elegante; "bajo los hechos declarados en la petición de Milligan, y las exposiciones presentadas, tenía legalmente la comisión militar, mencionada en la misma, jurisdicción para tratar de sentenciarlo? ${ }^{54}$ Después de enfatizar la ciudadanía estadounidense y el estatus civil de Milligan durante toda su vida, el Tribunal preguntó "[T]iene este Tribunal el poder legal y la autoridad para enjuiciar y castigar a este hombre?"55 Davis, un amigo de

${ }^{46}$ Ex parte Milligan, 71 U.S. 2 (1866).

${ }^{47}$ Cummings v. Missouri, 71 U.S. 277 (1867).

${ }^{48}$ Ex parte Garland, 71 U.S. 333 (1867).

${ }^{49}$ Milligan, 71 US. 68.

${ }^{50} \mathrm{Id}$.

${ }^{51} I d$.

${ }^{52} I d$.

${ }^{53} \mathrm{Id}$.

${ }^{54}$ Id. en 47.

${ }^{55}$ Currie con respecto a esta cuestión ha señalado que:

La pregunta se había evitado durante la propia guerra en Ex Parte Vallandigham, 68 U.S. (1 Wall.) 243 (1864), donde la Corte consideró que no era competente para examinar directamente la sentencia de una Comisión militar. De las diversas objeciones jurisdiccionales que se pincelan en Milligan, la única de interés era que el caso era discutible, porque debía presumirse que el peticionario había sido ahorcado como se había indicado. ' [I]ncluso la sugerencia [de que el ejército 
Lincoln desde hacía mucho tiempo, de quien Gustave Koerner escribe que "Lincoln era, creo, más íntimo con él que con cualquier otro hombre", y que a mediados de la década de 1840 llevó casos con Lincoln y también contra él como adversarios legales", ${ }^{56}$ emitió la opinión de la Corte. Currie observa que la discusión de "Davis" sobre la cuestión constitucional comienza con una de las afirmaciones de la corte más conmovedoras del Estado de Derecho. ${ }^{57}$ De hecho, la narrativa es una caracterizada por principios "demasiado simples y directos" como para invitar a la duda o ir más allá de la afirmación no calificada:

Este Tribunal nunca consideró cuestión alguna más grave, ni una que más concierna a los derechos de todo el pueblo; porque es el derecho de nacimiento de todo ciudadano americano, cuando se le acusa de un crimen, ser juzgado y castigado de acuerdo con la ley. El poder del castigo es, sólo a través de los medios que las leyes han provisto para ese propósito, y si son ineficaces, hay una inmunidad al castigo, no importa cuán grandioso delincuente el individuo pueda ser, o cuánto sus crímenes pueden haber conmocionado el sentido de Justicia del país, o puesto en peligro su seguridad. Por la protección de la ley los derechos humanos están asegurados; retirada esa protección, están a merced de gobernantes malvados, o del clamor de un pueblo excitado. Si había una ley para justificar este juicio militar, no está bajo nuestra responsabilidad interferir; si no la había, es nuestro deber declarar la nulidad de todo el procedimiento. La decisión de esta pregunta no depende de argumentos o precedentes judiciales, numerosos y muy ilustrativos como son. Estos precedentes nos informan de la magnitud de la lucha para preservar la libertad y para aliviar a aquellos de vida civil de los juicios militares. Los fundadores de nuestro gobierno estaban familiarizados con la historia de esa lucha; y aseguraron en una constitución escrita cada derecho que la gente había arrancado del poder durante un concurso de eras. Por esa Constitución y las leyes autorizadas esta pregunta debe determinarse. Las disposiciones de este instrumento sobre la administración de la justicia penal son demasiado claras y directas, para dejar espacio para la mala construcción o la duda sobre su verdadero significado....

La Constitución de los Estados Unidos es una ley para los gobernantes y los pueblos, igualmente en la guerra y en la paz, y cubre con el escudo de su protección a todas las clases de hombres, en todo momento, y bajo todas las circunstancias. Ninguna doctrina, que implique consecuencias más perniciosas, fue jamás inventada por el ingenio del hombre que cualquiera de sus disposiciones pueda suspenderse durante cualquiera de las grandes exigencias del gobierno. Tal doctrina conduce directamente a la anarquía o al despotismo, pero la teoría de la necesidad en la que se basa es falsa; porque el gobierno, dentro de la Constitución, tiene todos los poderes concedidos a ella, los cuales son necesarios para preservar su existencia; como felizmente se ha demostrado por el resultado del grandioso esfuerzo para desechar su justa autoridad. ${ }^{58}$

había ejecutado a Milligan mientras su caso estaba pendiente] ", dijo Davis," es perjudicial para el Ejecutivo, y la descartamos de una nueva consideración. ' De hecho, Milligan había sido indultado y más tarde fue liberado de acuerdo con la decisión de la Corte Suprema.

Currie Supra n. 45, en 134, n. 16 (se omiten las citas).

Sobre la hipótesis de si el Tribunal hubiese llegado a la misma "decisión audaz sobre el fondo" mientras la guerra civil estaba en pleno apogeo, véase, por ejemplo, Carl B. Swisher, Stephen J. Field, Artesano de la Ley (1930); Laurence H. Tribe, Ley Constitucional Americana 181 (1978). Currie también cita 6 Charles Fairman, Historia de la Corte Suprema de los Estados Unidos: Reconstrucción y Reunión, 1864 - 88, 185 - 237 (1971), sugiriendo una fuente que provea una narrativa completa y contextualización histórica del caso.

${ }^{56}$ Véase Willard L. King, Lincoln's Manager: David Davis en XI, 53 (1960). notas del rey:

En el circuito, Davis conoció con frecuencia a Lincoln, cuya práctica legal había aumentado a medida que su actividad política declinaba. A veces sus intereses chocaron. Lincoln derrotó a Davis en el caso mencionado anteriormente, en el que Davis empleó a Baker en la Corte Suprema. El registro de un caso de difamación en el Tribunal de circuito de Woodford en este período muestra a Davis \& Colton de un lado y a Lincoln en el opuesto; sin duda surgieron muchos de esos casos. Mientras Davis estaba en la legislatura, los papeles de St. Louis reportaron dos casos importantes siendo juzgados por Lincoln. La administración de Davis de la habilidad legal de Lincoln creció. En diciembre de 1845, Davis informó a Colton de un traje que había presentado para la firma en la corte de los Estados Unidos en Springfield. ' Lincoln, ' Davis afirmó ' piensa que el caso es claro. '

En casos específicos, Davis y Lincoln a veces se convirtieron en socios.

Id. en 53.

${ }^{57}$ Currie Supra n. 45.

${ }^{58}$ Milligan, 71 US. en $120-21$. 
62. En particular, ausente de este idioma, y de hecho de la mayor parte de la opinión, es cualquier referencia a la jurisprudencia, a los comentarios u otros análisis doctrinales. En cambio, encontramos una referencia resplandeciente y clarividente a los "derechos humanos" y la relación de estos derechos con la ley, la majestad de una Constitución inquebrantable, que es constante a través de la guerra y la paz, y al principio general del Estado de Derecho, al que todos los otros preceptos deben subordinarse. El tribunal volvió a la visión de los padres fundadores de una ley constitucional que es inalterable en su aplicación y que disipa, debido a principios evidentes, la necesidad de participar en cualquier otra forma de análisis legal. En este punto, la mayoría de los jueces son resonantemente claros; "la decisión de esta pregunta no depende de argumentos o precedentes judiciales, numerosos y muy ilustrativos como son." En este caso, por lo que el argumento sugiere, en sus artículos la Constitución "garantiza el derecho de juicio por jurado" y otros "valores para la libertad personal así encarnada", que simplemente no le fueron extendidos a Milligan. Es esta necesidad de reafirmar la libertad de los ciudadanos, la primacía constitucional y judicial, y el Estado de Derecho en un período de reconstrucción de una Unión fracturada a la que el juez Field se suscribió uniéndose a la mayoría. ${ }^{59}$ Esta historicidad no puede extraerse de la evolución de la doctrina de la inmunidad judicial y, por lo tanto, de la inmunidad del árbitro en el arbitraje internacional.

63. La euforia de este razonamiento jurídico, en el que participó el juez Field y su historicidad contextual, impregnó su sentido de misión como más alto funcionario del orden, capaz de marcar la diferencia, reforzando la credibilidad de los tribunales en particular y de las instituciones nacionales de manera más general. Los célebres "casos de juramento de prueba", en los que el juez Field rindió el dictamen de la Corte, llevaron a su aprobación a los casos de inmunidad judicial seminal: Randall v. Brigham y posteriormente Bradley v. Fisher. Ambos casos demuestran ser fundamentales en el desarrollo del derecho consuetudinario de los Estados Unidos de la doctrina de inmunidad del árbitro.

\section{Los Casos de Juramento de Prueba: Cummings v. Missouri y Ex parte Garland}

64. Cummings v. Missouri ${ }^{60}$ fue el primero de los dos "casos de juramento de prueba" muy elogiados. De hecho, la opinión mayoritaria que el juez Field también entregó en Ex parte Garland ${ }^{61}$ descansa en Cummings v. Missouri, aunque ambos casos reflejan una fecha de presentación idéntica del

\footnotetext{
${ }^{59}$ Currie observa, y con considerable apoyo textual, que
}

Davis comenzó en la dicta a echar atrás gran parte de ella. En primer lugar, admitió, que los soldados no tenían derecho a juicios por jurado por delitos militares, o que la quinta enmienda excepciona de su requisito de gran jurado ' casos que surgen en las fuerzas terrestres o navales, o en la milicia, en el servicio, en tiempo de guerra o peligro público, ' y' los redactores,... sin duda, quisieron limitar el derecho a un juicio por jurado, en la sexta enmienda, a aquellas personas que fueron sometidas a acusación o presentación en el quinta. ' [cita omitida] Aunque innecesaria a la decisión, esta concesión fue necesaria por la práctica de larga data y estaba de acuerdo con un dictum anterior [citando a Dynes $v$. Hoover, 61 U.S. (20 How.) 65, 79 (1858)]. Por otra parte, aunque uno puede sentirse intranquilo por la conclusión del Tribunal de que la excepción militar de la quinta enmienda se aplica también a la sexta, ayuda a conciliar la convicción de que los redactores no tenían la intención de abolir los tradicionales tribunales de guerra con el texto aparentemente inflexible de la Constitución.

Currie observa además que "[m]ás preocupante" es lo que sigue:

$\mathrm{Si}$, en la invasión extranjera o la guerra civil, los tribunales están realmente cerrados, y es imposible administrar la justicia penal de acuerdo con la ley, entonces en el teatro de las operaciones militares activas, donde la guerra realmente prevalece, hay una necesidad de proporcionar un sustituto de la autoridad civil, por tanto derrocada, para preservar la seguridad del ejército y la sociedad; y como no queda poder, sino el ejército, se le permite gobernar por ley marcial hasta que las leyes puedan tener su curso libre. Como la necesidad crea la regla, por lo que limita su duración; , si este gobierno continúa después de que se restituyan los tribunales, es una usurpación bruta del poder... Debido a que, durante la última rebelión [la regla marcial] podría haber sido aplicada en Virginia, donde la autoridad nacional fue revocada y los tribunales expulsados, no se sigue que debió obtenerse en Indiana, donde esa autoridad nunca fue disputada, y la justicia siempre se administró.

Currie Supra Nota 44, 135 - 36 (cursiva agregada).

${ }^{60}$ Cummings v. Missouri, 71 U.S. 277 (1867).

${ }^{61}$ Ex parte Garland, 71 U.S. 333 (1867). 
14 de enero de 1867. No es necesario una larga recitación fáctica para los propósitos actuales. Algunos hechos clave justifican mención, a pesar de que se ha derramado tinta significativa en la narración de la historia de los "casos de juramento de prueba".

65. Durante la "guerra civil", una frase que está notablemente ausente del dictamen de la Corte (incluido el disentimiento) y que fue sustituida eufemísticamente por el término "rebelión", se celebró una convención constitucional en todo el estado y se adoptó la nueva Constitución después de que la guerra terminara. ${ }^{62}$ La nueva Constitución del estado prescribió un juramento bastante elaborado, "dividido en sus partes separables, abrazando más de treinta afirmaciones o pruebas distintas". Sin embargo, en particular, a los efectos de este análisis:

no se requiere que el declarante niegue no sólo que nunca ha "estado en hostilidad armada contra los Estados Unidos, o a las autoridades legales del mismo" sino, entre otras cosas, que nunca, "por acto o palabra", manifestó su adhesión a la causa de los enemigos de los Unidos Estados, extranjeros o domésticos, o el deseo de su triunfo sobre las armas de los Estados Unidos, o su simpatía con los que se dedican a la rebelión, o alguna vez ha albergado o ayudado a cualquier persona que se dedica a la guerra de guerrillas contra los habitantes leales de los Estados Unidos, o ha entrado o salido del Estado con el propósito de evitar la inscripción o el reclutamiento en el servicio militar de los Estados Unidos; o, para escapar a la ejecución del deber en la milicia de los Estados Unidos, ha indicado alguna vez, en cualquier términos, su descontento con el gobierno de los Estados Unidos en su concurso con la rebelión. ${ }^{63}$

66. El apelante en el caso era un sacerdote de la iglesia católica romana, que fue acusado y condenado en un tribunal de juicio de Missouri "del crimen de enseñar y predicar como sacerdote y ministro de esa denominación religiosa sin haber tomado primero el juramento, y fue condenado a pagar una multa de $\$ 500$, y a ser confinado a la cárcel hasta que se pague el mismo." ${ }^{64}$

67. El Tribunal enmarcó la cuestión no como una cuestión "en cuanto a la existencia del poder del Estado sobre asuntos de policía interna, sino si ese poder ha constituido en el presente caso un instrumento para la imposición de castigo contra una prohibición de la Constitución." 65

68. La Corte consideró que la disposición constitucional de Missouri exigía tomar el juramento como condición necesaria para servir como maestro o servir como predicador en "cualquier iglesia, religión sociedad, o congregación", ${ }^{66} \mathrm{era}$ inconstitucional por tres motivos. En primer lugar, la mayoría de la Corte que se une al juez Field constató que impedir a una persona el ejercicio de una profesión constituía un "castigo" y no un derecho reservado a los estados de crear una cualificación para un puesto. Ciertamente, la Corte fue realmente asistida en su formulación, debido a la construcción muy estrecha de castigo que el abogado de Missouri formuló; a saber, "que" castigar a uno es privarlo de la vida, la libertad, o la propiedad, y que quitarle algo menos que esto no es un castigo en absoluto". ${ }^{67}$ La mayoría observó que "la descalificación de un cargo puede ser un castigo, como en los casos de condena tras la acusación. La descalificación de las actividades de una defensa legal, o de puestos de confianza, o del privilegio de comparecer en los tribunales, o de actuar como albacea, administrador o tutor, también puede, y a menudo se ha impuesto, como castigo. " (cita omitida) ${ }^{68}$

69. Habiendo concluido que el juramento de la Constitución de Missouri infligió un castigo y difícilmente un mero requisito previo o una cualificación para el ejercicio de una profesión o un puesto,

\footnotetext{
${ }^{62}$ Cummings, 71 U.S. en 322.

${ }^{63} \mathrm{Id}$.

${ }^{64} I d$.

${ }^{65}$ Id. en 319 .

${ }^{66} \mathrm{Id}$. en 317.

${ }^{67} \mathrm{Id}$. en 320

${ }^{68}$ Id.
} 
el camino fue pavimentado para concluir que el juramento fue elaborado con el fin de infligir castigo a un acto que no se castigaba en absoluto en el momento en que se cometió. Además, el carácter punitivo de la disposición de la Constitución de Missouri rogó la pregunta. ¿Qué posible relación podría existir entre la toma de un juramento que certifique que una persona no ha sido una ayuda o forma parte del gobierno confederado, y la cualificación o competencia de ese individuo para cumplir con las obligaciones profesionales en cuestión? ${ }^{69}$

70. En segundo lugar, habiendo llegado a la sólida conclusión de que las disposiciones de juramento de la Constitución de Missouri eran medidas punitivas, el Tribunal abordó la medida en que existía una prohibición en la Constitución de los Estados Unidos proscribiendo su observancia. Pidiendo prestado al juez jefe Marshall el lenguaje de Fletcher v. Peck ${ }^{70}$ concerniente a "las restricciones al poder legislativo de los estados," ${ }^{11}$ junto con la afirmación de que "la Constitución de los Estados Unidos [afirmativamente] contiene lo que puede considerarse una declaración de derechos para el pueblo de cada estado", el Tribunal consideró que el juramento de la Constitución de Missouri constituía un proyecto de ley de negación de derechos civiles. Por lo tanto, caía expresamente en el ámbito del artículo I, § 10 de la cláusula 1 de la Constitución. ${ }^{72}$ El razonamiento jurídico sobre la sección del dictamen que aborda los motivos por los que la disposición pertinente de la Constitución de Missouri es, sin más, un proyecto de ley de negación de derechos civiles, se erige como un modelo de esclarecedor análisis jurídico que, en parte, se basa en paradigmas históricos e hipótesis elaboradas e intrigantes que es tanto una defensa legal como un razonamiento analítico:

Si las cláusulas del segundo artículo de la Constitución de Missouri, a las que nos hemos referido, hubieran declarado que el Sr. Cummings era culpable, o debía ser declarado culpable, o había estado en hostilidad armada hacia los Estados Unidos, había entrado en ese estado para evitar ser matriculado o reclutado en el servicio militar de los Estados Unidos, y, por lo tanto, debía ser privado del derecho a predicar como sacerdote de la iglesia católica, o de enseñar en cualquier institución de aprendizaje, no cabe duda de que las cláusulas constituirían una lista de negaciones de derechos civile, en el sentido de la Constitución federal. Si estas cláusulas, en lugar de mencionar su nombre, hubieran declarado que todos

${ }^{69}$ El Tribunal de justicia razonó específicamente:

Las cualificaciones se refieren a la aptitud o la capacidad de la parte para una actividad o profesión en particular. Webster define que el término para referirse a ' cualquier dotación natural o cualquier adquisición que adapte a una persona para un lugar, oficina, o el empleo, o le permita sostener cualquier carácter, con éxito. ' Es evidente por la naturaleza de las actividades y profesiones de las partes, puestas bajo discapacidad por la Constitución de Missouri, que muchos de los actos, de cuya mancha deben purgarse, no tienen relación posible alguna con su aptitud para las actividades y profesiones. No puede haber ninguna conexión entre el hecho de que el Sr. Cummings ingresó o abandonó el estado de Missouri para evitar la inscripción o el reclutamiento en el servicio militar de los Estados Unidos y su aptitud para enseñar las doctrinas o administrar los sacramentos de su iglesia; tampoco puede un hecho de este tipo o la expresión de palabras de simpatía con algunas de las personas atraídas a la rebelión constituir evidencia de la inadecuación del abogado o consejero para ejercer su profesión, o del profesor para enseñar las ramas ordinarias de educación, o de la carencia de conocimientos empresariales o de capacidad de negocios en el Gerente de una corporación, o en cualquier Director o fideicomisario. Es manifiesto bajo la simple declaración de muchos de los actos y de las profesiones y actividades, que no existe tal relación entre ellos como para negar de la comisión de los actos todo lo apropiado como condición para permitir el ejercicio de las profesiones y actividades. Por lo tanto, no se ha exigido el juramento como medio de determinar si las partes están calificadas o no para sus respectivos llamados o la confianza con la que fueron depositados. Era necesario para llegar a la persona, no al llamado. Se exigió, no a partir de alguna noción de que los varios actos designados indicaban inadecuación para los llamados, sino porque se pensó que los variados actos merecen castigo, y que para muchos de ellos no había manera de infligir el castigo, excepto privando a la partes, que los habían cometido, de algunos de los derechos y privilegios del ciudadano.

Id. $319-20$.

${ }^{70}$ Fletcher v. Peck, 10 U.S. (6 Cranch) 87 (1810).

${ }^{71}$ Cummings, 71 U.S. en 322.

72 El artículo I, § 10, cláusula 1 de la Constitución de Missouri dice:

Ningún estado entrará en ningún tratado, Alianza o Confederación; otorgará Patentes de Corso y Represalia; moneda de dinero; emitirá Cartas de Crédito; hacer cualquier Cosa, salvo el oro y la moneda de plata en una licitación en el pago de deudas; aprobar cualquier proyecto de ley, ex post facto o ley que perjudique la Obligación de Contratos, u otorgar cualquier Título de Nobleza. 
los sacerdotes y clérigos del estado de Missouri eran culpables de estos actos, o debían ser declarados culpables de ellos, y por lo tanto, ser sometidos a una privación semejante, las cláusulas estarían igualmente abiertas a objeción. Y, además, si estas cláusulas hubieran declarado que todos los sacerdotes y clérigos debían ser declarados culpables, y ser así privados, siempre y cuando no hicieran, por un día designado, ciertos actos específicos, no estarían menos dentro de la prohibición de la Constitución federal.

En todos estos casos, la promulgación legislativa habría creado una privación sin ninguna de las formas ordinarias y guardias previstas para la seguridad del ciudadano en la administración de justicia por los tribunales establecidos. ${ }^{73}$

71. Esta hipótesis se analizó estrictamente en el marco de la Constitución de Missouri. El tribunal declaró que "las cláusulas supuestamente difieren sólo en que declaran la culpabilidad en lugar de asumirla. La privación se efectúa con la misma certeza en un caso y en el otro, pero no con la misma franqueza." Llegó a la conclusión de que "[e]l propósito del legislador en los casos, supuestamente, sería abiertamente declarado; en el caso existente sólo se disfraza. El resultado legal debe ser el mismo, porque lo que no se puede hacer directamente no se puede hacer indirectamente. La Constitución se ocupa de la sustancia, no de las sombras. Su prohibición fue contra la cosa, no contra el nombre. Se pretendía que los derechos del ciudadano se aseguraran contra la privación por conductas pasadas mediante la promulgación legislativa, en cualquier forma disfrazada. Si la prohibición puede ser eludida por la vía de la promulgación, su inserción en la ley fundamental fue un proceso vano e inútil". ${ }^{74}$

72. El juez Field era consciente de que la cláusula controvertida en la Constitución de Missouri era engañosa, incluso tras el examen de la superficie, cuando se veía a través de la óptica de un posible análisis ex post facto de la ley. De acuerdo con un paradigma legal ortodoxo, parecería que el juramento constitucional de Missouri no era una ley ex post facto porque no (i) proscribía un delito o (ii) bajo una construcción de significado llano pretendía imponer un castigo. Por lo tanto, el juramento constitucional de Missouri no parecía, a un nivel literal, satisfacer los elementos de una ley ex post facto porque no había una promulgación de ley definiendo un crimen y el castigo correspondiente. La propia Corte reconoció que "[p]or una ley ex post facto se entiende una que impone un castigo por un acto que no fue punible en el momento en que se cometió; o impone un castigo adicional al prescrito; o cambia las reglas de evidencia por las cuales un testimonio menor o diferente del que entonces se requería es suficiente para condenar". ${ }^{75}$ Ciertamente la construcción estricta afirmará, al igual que la disidencia, ${ }^{76}$ que el juramento, tanto en forma como en sustancia, no corresponde a la marca. Esto fue lo que la Corte pareció conceder.

73. De hecho, a pesar del reconocimiento de que "las cláusulas de la Constitución de Missouri, que son objeto de consideración, no definen, en sus términos, ningún delito, ni declaran que se infligirá ningún castigo", la opinión, sin embargo, aclara que "producen el mismo resultado sobre las partes, contra quienes se dirigen, como si fueran definidos los crímenes y el castigo fuese declarado."77 (énfasis Añadido)

74. El análisis se centra en la aplicación práctica del lenguaje, no en su construcción literal. Además, al tiempo que se afirma la importancia y el alcance de las facultades reservadas a los estados, la mayoría reconoce que la solidez normativa de la Constitución, y por lo tanto de la teoría política y la institución de la joven República, más que nunca debe apoyarse. En consecuencia, la Corte revocó la sentencia de la Corte Suprema de Missouri y reenvió el asunto con la instrucción de emitir una sentencia que revierta a la Corte de Circuito, "y ordenando a dicha corte liberar al acusado de encarcelamiento, y permitirle salir sin orden de regreso."78

\footnotetext{
${ }^{73}$ Cummings, 71 U.S. en $324-25$.

${ }^{74}$ Id. en 325 .

${ }^{75}$ Id. $325-26$

${ }^{76}$ Véase Ex parte Garland, 71 U.S. 333 (1867).

77 Cummings, 71 U.S. en 327.

${ }^{78}$ Id. en 331 .
} 
75. Ex parte Garland planteó doctrinal y conceptualmente a la Corte una cuestión idéntica planteada en Cummings v. Missouri. En lugar de abordar un juramento de prueba en el contexto de una disposición constitucional estatal, la cuestión en el caso Garland surgió de conformidad con una ley federal de juramento de prueba que el Congreso había aprobado en 1862. A pesar de que el acto era prospectivo al exigir a todos los funcionarios federales que tomasen el cargo después de la promulgación de la legislación nunca haber portado armas contra los Estados Unidos luego de convertirse en un ciudadano, era sustancialmente tan comprensiva como su contraparte constitucional de Missouri. De hecho, el juramento proscribió cualquier simpatía previa, por afiliación o con lealtad, al gobierno Confederado. ${ }^{79}$

76. En 1865, tres años después de su promulgación, el juramento fue enmendado para incluir a los "abogados y consejeros de los tribunales de los Estados Unidos." ${ }^{80}$ Además de ser administrado bajo pena de perjurio, se prohibiría a un abogado o consejero de los tribunales de los Estados Unidos que tuviera una oficina "bajo los Estados Unidos" si declaraba falsamente haber jurado. ${ }^{81}$

77. Es evidente que la intención y el propósito de la ley original de 1862 era limpiar el gobierno, por lo que el argumento afirma, de individuos que de otra manera estarían estratégicamente colocados para ayudar y asistir a sus enemigos. El segundo acto fue menos estratégico y más remunerativo, pero para una clase especial de practicantes; a saber, los que habían permanecido leales a la Unión. Swisher describió de manera más adecuada y elocuente el segundo acto y su propósito como "el ' sistema de botín ' aplicado a la situación de la posguerra." 82

78. El apelante, A. H. Garland había sido un abogado practicante ante la Corte Suprema a partir de diciembre de 1860. Más tarde, sin embargo, sirvió como miembro del Congreso en el gobierno Confederado al recibir un indulto presidencial completo. En 1865 solicitó a la Corte el permiso para reanudar su práctica y, por lo tanto, estar exento de tomar el juramento, al que no podía jurar y suscribirse sin incurrir en perjurio. ${ }^{83} \mathrm{La}$ administración del juramento operaría en cuanto al apelante y a los individuos en situación similar "como un decreto legislativo de exclusión perpetua". ${ }^{84}$ Antes de buscar el apoyo analítico de Cummings v. Missouri, el único caso que la mayoría de la Corte citó como precedente, al entregar el dictamen de la Corte el juez Field señaló:

Como el juramento prescrito no puede ser tomado por las partes, el acto funciona, en su contra, como un decreto legislativo de exclusión perpetua. Y la exclusión por conductas pasadas, para muchas de las profesiones o cualquiera de las ocupaciones ordinarias de la vida, puede considerarse bajo ninguna otra luz que como castigo para tal conducta. La exigencia del juramento es el modo previsto para determinar las partes a las que el acto está destinado a operar y, en lugar de disminuir, aumenta su carácter objetable. Todas las representaciones de este tipo participan de la naturaleza de penas y sanciones, y están sujetas a la prohibición constitucional contra el paso de los proyectos de ley de negación de derechos, bajo la cual se incluyen las designaciones generales. ${ }^{85}$

${ }^{79}$ El lenguaje de la ley federal de prueba de juramento de 1862 fue: "yo [------] juro solemnemente (o afirmo) que nunca he dado voluntariamente ayuda alguna, aceptación, consejo o aliento a las personas que se dedican a la hostilidad armada misma."

${ }^{80}$ Véase Cummings, 71 U.S. en 317 ("ninguna persona, después de la expiración de los 60 días, está autorizada, sin tomar el juramento, ' para ejercer como abogado o consejero legal, ni después de ese período puede cualquier persona ser competente, como obispo, sacerdote, diácono, ministro, anciano o clérigo, de cualquier persuasión religiosa, secta, o denominación, para enseñar, o predicar, o solemnizar los matrimonios".).

${ }^{81} I d$. ("La multa y el encarcelamiento se prescriben como castigo por la tenencia o el ejercicio de cualquiera de las "oficinas, posiciones, fideicomisos, profesiones o funciones "especificadas, sin haber tomado el juramento; y falsamente jurar o afirmar tomarlo, es declarado como perjurio, castigable con prisión en la penitenciaría".).

${ }^{82}$ Swisher, Supra n. 56, al 139.

${ }^{83}$ Ex parte Garland, 71 U.S. 333, 375 (1867).

${ }^{84} I d$. en 377.

${ }^{85} I d$. 
79. La proximidad de Ex parte Garland para Cummings v. Missouri es tal que la opinión disidente para ambos casos sólo se publicó en Ex parte Garland y no puede encontrarse en Cummings v. Missouri. En ambos casos, el jefe de justicia Chase fue acompañado por los jueces David Davis, Samuel Miller y Noah Swayne de Ohio. ${ }^{86}$ El papel del juez Field en Ex parte Milligan, como parte de la mayoría acompañando al juez Davis en la opinión, y como la justicia que habló por la mayoría de la Corte en los Casos de Juramento de Prueba, simplemente no puede entenderse como, conceptual y doctrinalmente, análoga a la mayoría de las opiniones que entregó a la Corte en el casos de inmunidad: Randall v. Brigham y Bradley v. Fisher. Estos tres casos, Ex parte Milligan, Cummings v. Missouri, y Ex parte Garland, mucho más allá de la cuestión particular abordada, fueron existenciales para la nueva República.

80. Los tres demostraron que si, de hecho, la Corte Suprema puede ser mal caracterizada como "la rama menos peligrosa", durante el período de reconstrucción, ciertamente demostró ser el centro de gravedad armonizador de la República. El juez Field era muy consciente de la necesidad de un poder judicial imparcial e independiente que fomentaría los fundamentos teóricos de un cambio de paradigma constitucional, social, económico e interracial en evolución. Los desafíos de la reconstrucción comandaban un sistema judicial inexpugnable. Es la historicidad del pensamiento del juez Field en Ex parte Milligan, Cummings v. Missouri y Ex parte Garland la que debía suministrar el marco conceptual en el que fueron decididos los casos seminales de inmunidad judicial.

81. Nada salvo una consolidación judicial absoluta podría haber sido considerada aceptable. Sin embargo, esa historicidad es ajena a la inmunidad del árbitro. Su relevancia, desarrollo doctrinal y configuración histórica no pueden importarse al por mayor y aplicarse a la inmunidad absoluta del árbitro, y mucho menos sobre la base de un argumento por analogía: es decir, que la similitud resolutiva entre el juez y árbitro de alguna manera ordena injertar el desarrollo doctrinal de la inmunidad judicial en la inmunidad del árbitro. En pocas palabras, los acontecimientos históricos que dieron lugar a la inmunidad judicial simplemente no pueden aplicarse a la inmunidad del árbitro. Lamentablemente, lo han sido.

82. No se han dibujado las distinciones necesarias y apropiadas. Sobre la fuerza de la argumentación por analogía, la inmunidad del árbitro ha sido fundamentada, sin calificación, en la inmunidad judicial. Este desarrollo hace una vista ciega y un oído sordo a ambos (i) la naturaleza de la adjudicación judicial, y (ii) la historia de la inmunidad judicial.

\section{Bradley v. Fisher: La Maduración de la Inmunidad Judicial}

83. En 1872, apenas tres años después de su pronunciamiento sobre el alcance y los elementos de la inmunidad judicial en Randall v. Brigham, la Corte Suprema expresó su insatisfacción con la formulación de la doctrina anunciada en esa opinión. Aunque expansivos y funcionalmente casi absolutos, los contornos de la inmunidad tenían excepciones susceptibles de impugnación. La inmunidad parecía prácticamente absoluta, pero estaba lejos de ser imposible de contradecir. Estas cualificaciones, sin embargo, proporcionaron al campo de la justicia una razón suficiente para concluir que había espacio para reforzar la doctrina y, por lo tanto, el poder judicial como pilar institucional.

84. La formulación de Randall v. Brigham proporcionó dos cualificaciones para la recitación básica de la inmunidad, estableciendo que "es un principio general aplicable a todos los funcionarios

${ }^{86} \mathrm{Al}$ concluir la opinión de la mayoría en Cummings v. Missouri el texto de la opinión dice:

el Magistrado Jefe, y los Sres. Magistrados Swayne, Davis, Miller disidente.

En nombre de esta parte de la Corte, el Sr. Magistrado Miller dictó una opinión disidente. Este dictamen se aplica por igual o más al caso de Ex parte Garland (el caso siguiente), que involucró los principios de un carácter similar a los discutidos en este caso. Por lo tanto, el dictamen disidente se publica tras el dictamen de la Corte en dicho asunto [Ex parte Garland].

Cummings, 71 U.S. en 332. 
judiciales, que no sean responsables a una acción civil por cualquier acto judicial hecho dentro de su jurisdicción." ${ }^{17}$ Esta amplia formulación se clasificó primero añadiendo que "se ha sostenido que [los jueces de autoridad limitada e inferior] están protegidos sólo cuando actúan dentro de su jurisdicción." 88 En segundo lugar, a pesar de que se afirma que "no existe tal limitación con respecto a los jueces de autoridad superior o general," ${ }^{189}$ la proposición sostiene que la responsabilidad puede "tal vez"90 cuestionarse "cuando los actos, en exceso de jurisdicción, se hacen maliciosa o corruptamente". ${ }^{11}$ Calificaciones en cuanto a la situación del juez y lo que parece ser el elemento Scinter se percibía que constituían debilidades doctrinales que obligaban a una reparación.

85. La oportunidad de abordar estas cuestiones, como parte del esfuerzo sistémico para fortalecer el poder judicial, reconstruir la nación y desarrollar las libertades civiles en el marco de la decimotercera y Decimocuarta Enmienda, surgió en la forma de lo que puede ser exactamente descrita como una placa de Petri de los hechos impares, históricos y traumáticos que comprenden Bradley v. Fisher. La importancia histórica del caso es tanto más significativa porque se desarrolla durante el juicio de junio 1867 de John H. Surratt, por el asesinato de Abraham Lincoln. ${ }^{92}$ El juicio por homicidio se celebró en la Corte Penal del Distrito de Columbia. El caso fue presidido por el juez George P. Fisher, un designado por Lincoln para servir en la recién creada Corte Suprema del Distrito de Columbia, después de haber servido en un tribunal de reclamaciones sobre Brasil en fomento de una comisión del Presidente Zachary Taylor, y como Procurador General del estado de Delaware. El juicio de Suratt por la conspiración del asesinato concluyó en agosto de 1867 cuando el jurado, incapaz de arribar a un veredicto, ${ }^{93}$ fue dado de alta el 10 de agosto de 1868.

\footnotetext{
${ }^{87}$ Randall v. Brigham, 74 U.S. 523, 535 - 36 (1869).

${ }^{88} \mathrm{Id}$.

${ }^{89} I d$.

${ }^{90} I d$. (cursiva agregada).

${ }^{91} I d$.

${ }^{22}$ Bradley v. Fisher, 80 U.S. 335, 344 (1871).

${ }^{93}$ La transcripción literal del controvertido juicio en el que se llevó a cabo claramente un aborto de la justicia dice lo siguiente con respecto a la aprobación de la gestión del jurado:

Sábado, 10 de agosto de 1867. A la una de la tarde, el fiscal distrito, y el prisionero y estando presente su abogado, el jurado apareció en la corte.

El secretario [p]uso las preguntas habituales: ' señores del jurado, ¿han acordado un veredicto?' El Sr. Todd respondió con la negativa

el C ] i: RT [ortografía en el original] dijo que había recibido esta mañana la siguiente comunicación por escrito del jurado:

Al Honorable Jorge P, Fisher, juez de la Corte Penal:

Señor: el jurado en el caso de los Estados Unidos vs John H. Surratt, muy respetuosamente, afirman que se encuentran precisamente ahora como cuando fueron elegidos por primera vez para entrar en el salón, casi igualmente divididos, y están firmemente convencidos de que no pueden hacer un veredicto. Consideramos que es nuestro deber para con la corte, para el país, y en vista de la condición de nuestros asuntos privados y la situación de nuestras familias, y en vista del hecho de que la salud de varios de nuestros miembros se está deteriorando gravemente bajo el prolongado confinamiento, y para hacer esta declaración, y pedirle a su Señoría que nos despida de inmediato.

Muy respetuosamente presentado:

W. B. TODD

ROBT. Bola.

J. RUSSELL BARR.

Geo. A. BOHRER.

SCHNEIDER.

JAMES Y. DAVIS.

COLUMBUS ALEXANDER.

WM. McLEAN.

Benj. G. MORSELL.

B.E. GITTINGS.

W. W. NACIMIENTO.

El Tribunal preguntó si no había alguna cosa para ser dicha por el jurado debería ser dado de baja ahora.

El Señor Bradley dijo que el prisionero no dio su consentimiento a ninguna liberación del jurado. Si iban a ser dados de alta, él deseaba que entendieran que estaba en contra de su voluntad y protesta.

El fiscal del distrito, en nombre del gobierno, dejó todo el asunto a discreción de la corte.
} 
86. El demandante en la acción subyacente fue Joseph H. Bradley, un abogado que practicaba ante la Corte Suprema del Distrito de Columbia. Bradley interpuso un reclamo contra el juez Fisher, en busca de daños por supuestas lesiones que el juez Fisher le hizo sufrir "por los actos deliberados, maliciosos, opresivos y tiránicos" del juez, que presumiblemente impidieron que Bradley ejerciera su derecho a practicar la abogacía ante la Corte Suprema del distrito de Columbia.

87. Específicamente, al descargar al jurado, el juez Fisher emitió una orden que prohibió a Bradley la práctica del derecho ante la Corte Penal del Distrito de Columbia. La orden contenía un recital narrando que el 2 de julio de 1867 durante el juicio de Surratt, "inmediatamente después de que el Tribunal había tomado un receso por el día, cuando [el juez Fisher] descendía del Banco, había sido abordado de una manera grosera e insultante por [Bradley, abogado del acusado John H. Surratt], acusando [al juez Fisher] de haber ofrecido [a Bradley] una serie de insultos desde el estrado desde el comienzo del juicio: que el juez entonces había negado toda intención de avanzar cualquier insulto en absoluto, y había asegurado al demandante que no le había animado ningún otro sentimiento más que el de respeto, pero que el demandante, lejos de aceptar esta explicación, o descargo de responsabilidad, había amenazado al juez con un castigo personal. "94

88. Una rareza adicional, que contribuye a la configuración fáctica extraordinaria del caso, es que la queja de Bradley se basó en un error fundamental por su parte, con respecto al cual, de alguna manera, concluyó que la orden del juez Fisher le impidió practicar ante la Corte Suprema del Distrito de Columbia, cuando de hecho, consonante con la orden, su nombre había sido eliminado del rol de abogado practicante ante el Corte Penal del Distrito de Columbia. ${ }^{95}$ A pesar de la notoria frivolidad de la afirmación que se basaba en un simple error ${ }^{96}$ la Corte aprovechó la oportunidad para reformular la doctrina de la inmunidad. Procedería a eviscerar (i) la limitación relativa a los jueces de la corte inferior, y (ii) el Scinter.

La Corte señaló que esta era la tercera comunicación de un tenor similar que había recibido del jurado. Si él pensara que había alguna posibilidad de que llegaran a un acuerdo en cuanto a la culpabilidad o la inocencia del prisionero, no tendría ninguna objeción a mantenerlos fuera más tiempo; pero suponiendo, a partir de la declaración hecha por ellos, que no se podía esperar ningún resultado, dirigió al jurado [ortografía original] ser descargado.

El prisionero fue enviado a la custodia del alguacil.

II juicio de John H. Surratt en el Tribunal Penal para el distrito de Columbia, el Honorable George P. Fisher, PRESIDIENDO, en 1379 (1867).

94 Bradley, 80 U.S. en 344.

${ }^{95}$ El récord real que mantiene la Oficina de Asuntos Nacionales memorizando el pronunciamiento del juez Fisher refleja que la orden dice:

En el 2do día de julio pasado, durante el progreso del juicio de John H. Surratt por el asesinato de Abraham Lincoln, inmediatamente después de que la corte había tomado un receso hasta la mañana siguiente, cuando el juez que presidía descendía del estrado, Joseph H. Bradley, Esq., lo abordó de una manera grosera e insultante, acusando al juez de haberle ofendido (al Sr. Bradley) con una serie de insultos desde el estrado desde el comienzo del juicio. El juez negó cualquier intención de avanzar cualquier insulto en absoluto, y aseguró al Sr. Bradley que a él no le animaban otros sentimientos que los de respeto. El Sr. Bradley, lejos de aceptar esta explicación o descargo de responsabilidad, amenazó al juez con el castigo personal. Ningún tribunal puede administrar justicia ni vivir si sus jueces son amenazados con un castigo personal en todas las ocasiones, siempre que la irascibilidad del abogado se vea excitada por un insulto imaginario. El delito del Sr. Bradley es uno que ni siquiera sus años pueden paliar. No se puede pasar por alto ni quedar impune. Por lo tanto, se ordena que su nombre sea borrado del rol de abogados que practican en este Tribunal.

GEORGE P. FISHER

Juez de la Corte Suprema D.C.

Id. en 337 .

${ }^{96}$ En cuanto a esta tesis, el Tribunal de Justicia manifestó ampliamente su conciencia del error, que a su vez da mayor peso al sentido de urgencia que se asocia a su percepción de la necesidad de complementar la norma de inmunidad judicial:

El demandante parece haber considerado esta orden del Tribunal Penal como una orden que lo desbaría de la Corte Suprema del distrito; y toda la teoría de la presente acción procede sobre esa hipótesis. La declaración en un conteo describe el Tribunal Penal como una de las ramas de la Corte Suprema, y en el otro recuento representa el orden del Tribunal Penal como una orden de retirar al demandante de la oficina de un abogado en la Corte Suprema de la Distrito. Y es por la supuesta expulsión de ese tribunal, y los supuestos daños consiguientes al respecto, que la acción es llevada. Id. en 345 . 
89. Revisando su participación en Randall v. Brigham, en cuanto al idioma calificado de "a menos que, tal vez, cuando los actos en exceso de jurisdicción se hagan de manera maliciosa o corrupta", el Tribunal razonó que estas "palabras calificativas se insertaron bajo la sugerencia de que el idioma anterior establecía la doctrina de la exención judicial de responsabilidad a las acciones civiles en términos más amplios de lo necesario para el caso bajo consideración, y que si el idioma seguía sin estar calificado requeriría una explicación sobre algunas aparentemente conflictivas adjudicaciones encontradas en los reportes. No se pretendía como una expresión de opinión de que en supuestos casos tal responsabilidad existiría, sino para evitar la expresión de una doctrina contraria". ${ }^{97}$ El principio de gobierno se formuló dentro de un marco de inmunidad absoluta. El principio aplicable que define ahora la inmunidad judicial reconoce que "los jueces de Cortes con jurisdicción superior o general no son responsables de acciones civiles por sus actos judiciales, incluso cuando tales actos son superiores a su jurisdicción, y se alega que se han hecho maliciosa o corruptamente." ${ }^{198}$ En cuanto al término "en exceso de su jurisdicción" se trazó una distinción entre una "ausencia clara de toda jurisdicción sobre el tema" y un "exceso de jurisdicción". Se estableció un espacio estrecho para una posible responsabilidad en relación con casos extraordinarios, en los que la ausencia obvia e inequívoca de cualquier jurisdicción sobre la materia, obligaría a la conclusión de que se había usurpado la autoridad judicial, garantizando así la responsabilidad. En cambio, el "exceso de jurisdicción" se definió como un lugar común que justifica la protección contra la inmunidad:

Cuando claramente no exista jurisdicción sobre la materia, toda autoridad ejercida es una autoridad usurpada, y para el ejercicio de dicha autoridad, cuando el juez conoce la carencia de jurisdicción, no hay excusa permitida. Pero cuando la jurisdicción sobre la materia sea investida por la ley en el juez, o en la Corte que él mantiene, la manera y el alcance en que se ejercerá la jurisdicción son, generalmente, preguntas para su determinación, tanto como cualquier otra pregunta involucrada en el caso, aunque sobre la exactitud de su determinación en estos detalles la validez de su juicio pueda depender. (énfasis añadido) ${ }^{99}$

90. A pesar de su condición de caso seminal sobre la cuestión de la inmunidad judicial, la riqueza doctrinal de la decisión y del análisis correspondiente se ha pasado por alto. Ciertamente hay acuerdo en que Bradley v. Fisher es el caso seminal sobre la cuestión de la inmunidad judicial. La profundidad y la riqueza de su participación, sin embargo, se ha pasado por alto porque el principio del derecho, por el que se mantiene como una cuestión de conveniencia, ha sido abreviado a la proposición de que a los jueces se les ha concedido inmunidad absoluta de enjuiciamiento civil. Esta iteración de la orden en Bradley v. Fisher omite la única excepción que aborda la usurpación de la autoridad. Esta omisión es sumamente esencial para la comprensión de (i) el desarrollo de la inmunidad del árbitro, (ii) las razones por las que la importación al por mayor de la inmunidad judicial en la doctrina de la inmunidad absoluta del árbitro es disfuncional, y (iii) una premisa en apoyo de la afirmación de que la inmunidad absoluta del árbitro conduce necesariamente a la sobreprotección.

\footnotetext{
${ }^{97} I d$. en 350.

98 Id. en 350.

99 Id. en 350 (cursiva agregada).

En aras de la exhaustividad, se proporcionó un ejemplo de un caso en el que "claramente no hay jurisdicción" y, por lo tanto, está presente la usurpación de la autoridad judicial:

Por lo tanto, si un tribunal de sucesiones, invertido sólo con la autoridad sobre los testamentos y la liquidación de las propiedades de las personas fallecidas, debe proceder a tratar a las partes por delitos públicos, la jurisdicción sobre el tema de los delitos que están totalmente queriendo en el Tribunal, y esto es necesariamente conocido por su juez, su Comisión no le daría protección en el ejercicio de la autoridad usurpada. Pero si, por el contrario, un juez de un Tribunal Penal, investido con la jurisdicción penal general sobre los delitos cometidos en un determinado distrito, debe tener un acto particular para ser un delito público que no es por la ley tipificada como delito, y proceder a la detención y TR IAL de una parte acusada de que tal acto, o debe sentenciar a una parte condenada a una sanción mayor que la autorizada por la ley en su debida construcción, ninguna responsabilidad personal a la acción civil por tales actos se adjuntaría al juez, aunque esos actos estarían en exceso de su jurisdicción, o de la jurisdicción del Tribunal de que dispone, ya Id. que se trata de detalles para su consideración judicial, siempre que se invoque su jurisdicción general sobre el asunto.
} 
91. La usurpación de autoridad, elemento de inmunidad judicial, no puede conceptualmente aplicarse a la inmunidad del árbitro. En los casos de arbitraje comercial internacional la doctrina de Kompetenz-Kompetenz haría que un análisis con base en la usurpación de la autoridad resultara prácticamente irrelevante, aun cuando la imaginación fuere a conjurar una configuración fáctica en la que dicho análisis se considerara aplicable. ${ }^{100}$ Los límites doctrinales establecidos para la autonomía de las partes y la arbitrabilidad, casi con certeza, excluyen cualquier probabilidad razonable de casos similares a la usurpación de la autoridad judicial que la Corte explicó y describió en Bradley v. Fisher. ${ }^{101}$

\section{La Transposición de la Inmunidad Judicial a la Inmunidad Arbitral: El Cambio de Paradigma que Conduce a la Sobreprotección Sin Fundamento Normativo, Histórico o de Políticas}

92. La inmunidad judicial absoluta prácticamente no calificada ha sido objeto de incorporación en la esfera del arbitraje internacional. Este desarrollo doctrinal ha madurado sin el beneficio de, al menos ocho, proposiciones no exhaustivas que configuraron y reconfiguraron el desarrollo y la expansión de los límites de la inmunidad judicial absoluta. El desarrollo, a su vez, dio lugar en el derecho consuetudinario a un grupo de inmunidades judiciales relacionadas. ${ }^{102}$ Desde un principio, ausente del desarrollo de la inmunidad arbitral está la rica historicidad que subyace en el desarrollo de la doctrina de la inmunidad judicial. Por lo tanto, la regla absoluta de inmunidad al árbitro carece de los momentos cruciales de la transformación histórica tanto inglesa como estadounidense, (i) las consecuencias naturales de la doctrina de que "el rey no puede hacer nada malo"103 y (ii) el vector social-histórico de una Corte Suprema de los Estados Unidos de la era de la reconstrucción de la guerra civil que generó la doctrina de inmunidad judicial absoluta. ${ }^{104}$

93. La doctrina de inmunidad absoluta al árbitro no es una heredera legítima de este legado histórico. En cambio, la doctrina fue el producto de un tour de force teniendo como causa y primer principio una analogía más que una serie de momentos históricos muy concretos, que se centraron en el funcionamiento específico de los tribunales judiciales como expresiones de la soberanía institucionalizada que debían salvaguardar a toda costa. Ningún alegato comparable puede atribuirse al papel de un árbitro en un arbitraje comercial internacional o en una disputa con base en tratados.

94. En segundo lugar, los casos estrechos que dan origen a la responsabilidad judicial en las reivindicaciones civiles, con base en una absoluta falta de jurisdicción, equivalen a un "abuso de jurisdicción", tanto teóricamente como prácticamente, ausente de los procedimientos arbitrales. Ninguna de esas excepciones a la responsabilidad puede formar parte de un marco basado en el consentimiento de las partes y circunscrito por las doctrinas de arbitrabilidad y competencia.

95. En tercer lugar, los sistemas de control comunes a los procedimientos judiciales minimizan la necesidad de acciones de daños civiles privados como un control apropiado de las infracciones judiciales. Los procedimientos de arbitraje carecen de sistemas de control y rendición de cuentas comparables por la mala conducta del árbitro. Por lo tanto, la utilización de causas privadas de acción como

\footnotetext{
${ }^{100}$ Véase supra n. 60.

${ }^{101} \mathrm{El}$ análisis no sería materialmente diferente con respecto a los arbitrajes inversionista-estado basados en tratados. De hecho, en cuanto a los procedimientos arbitrales presentados ante el centro internacional para la solución de controversias en materia de inversiones ("CIADI"), el proceso de cribado realizado como un predicado de registro de conformidad con el artículo 36 (3) del Convenio del CIADI y la regla de la institución 6, establecer además la inaplicabilidad de un análisis de la usurpación de la autoridad en el contexto del arbitraje internacional en general.

${ }^{102}$ Ampliación de la inmunidad judicial a funcionarios, contadores, ingenieros, entre otros. Véase, por ejemplo., Durham v. Reidsville Engineering Co., 120 S. E. 2D 564 (N.C. 1961); Craviolini v. Scholer \& Fuller Associated Architects, 357 P. 2D 611 (Ariz. 1960); Wilder v. Crook, 34 Soo. 2D 832 (ala. 1948).

103 Véase supra 9 甲 23 - 35.

104 Véase supra $990-63$.
} 
recurso apropiado para crear un efecto inhibidor de la mala conducta del árbitro y para corregir los abusos de los árbitros es más justificada.

96. Cuarto, la inmunidad judicial y el grupo derivado de inmunidades que se adhieren al sector público, tienen actores cuyas responsabilidades son esenciales para el proceso judicial e igualmente necesarias para los fines de ejercer la soberanía del Estado a través de los sistemas judiciales y administrativos (reglamentarios). Están sujetos a controles y equilibrios jerárquicos sistémicos dentro de la estructura de las agencias. Todo este marco de referencia está ausente del arbitraje internacional y del papel de los árbitros. Además, estos funcionarios que forman parte del proceso judicial están (i) bajo el escrutinio oficial del gobierno y (ii) sujetos a restricciones de divulgación en registros públicos que hacen que sus decisiones sean susceptibles a las evaluaciones de rendimiento del público y a los efectos consecuentes de dichas evaluaciones públicas. ${ }^{105} \mathrm{El}$ arbitraje comercial internacional es privado y $\mathrm{Ad}$ hoc. ${ }^{106}$ Por lo tanto, la necesidad de derechos de acción privados contra los árbitros está más reforzada.

97. Quinto, los contornos del desarrollo y la expansión de la doctrina de la inmunidad judicial, en parte, se basaron en el análisis de las fases de los procedimientos judiciales que (i) no tienen análogo alguno en los procedimientos arbitrales, y (ii) suelen exponer a los actores públicos que forman parte de la judicialidad, incluidos jueces y magistrados, a todo un universo de terceros no- partes con los que los árbitros no tienen tratos. ${ }^{107}$

98. De ello se deduce que los funcionarios judiciales que son esenciales para la ejecución de las órdenes judiciales, por ejemplo, tienen el equivalente de una inmunidad judicial con base en una construcción expansiva de esa doctrina bajo la consideración de estos dos factores. ${ }^{108}$ La ejecución de órdenes judiciales y juicios habitualmente concierne o afecta a terceros no-partes y, por lo tanto, crea una mayor exposición para los jueces y otros actores judiciales, los cuales son completamente ajenos a los procesos arbitrales. Independientemente de las voces que afirman que los procedimientos arbitrales son actos internacionales autónomos que no están sujetos a limitaciones geopolíticas, ${ }^{109} \mathrm{el}$ hecho es que los laudos internacionales de arbitraje comercial no son, ni pueden ser, autoejecutables. Debido a estas razones, naturaleza y construcción, su eficacia y aplicación práctica definitiva dependen totalmente de los tribunales judiciales. ${ }^{110}$

105 Véase Ley de mejoramiento de la FOIA de 2016, señalando que las presentaciones judiciales y los registros públicos están abiertos al público. California, Colorado, Nueva Jersey, Texas y Washington, entre otros, tienen sus propios estatutos relativos a los registros públicos.

${ }^{106}$ Supra n. 3.

107 Supra 9 ๆ $7-9,81-82$.

108 Véase supra $\uparrow 14-16,80-82$.

109 Véase Sitio web del CIADI, descripción de los procesos (consultado el 12 de marzo de 2019), https://icsid.worldbank. org/en/pages/process/overview.aspx, estableciendo: "el Convenio del CIADI establece el marco procesal básico para la conciliación y el arbitraje de los litigios de inversión que surjan entre los Estados miembros del CIADI y los inversores que califican como nacionales de otros Estados miembros. Es un tratado entre los Estados miembros que establece un sistema independiente, imparcial y autónomo." (cursiva agregada).

${ }^{110}$ Véase Convención de las Naciones Unidas sobre el reconocimiento y ejecución de las sentencias arbitrales extranjeras, en el artículo $\mathrm{V}$, por la que se establece:

1. El reconocimiento y la ejecución de la adjudicación podrán denegarse, a petición de la parte contra la que se invoca, únicamente si dicha parte le suministra a la autoridad competente en la que se solicita el reconocimiento y la ejecución, prueba de que:

un Las partes en el acuerdo a que se refiere el artículo II eran, en virtud de la ley aplicable a ellos, bajo cierta incapacidad, o dicho acuerdo no es válido en virtud de la ley a la que las partes la sometieron o, en su defecto, en virtud de la legislación del país donde se realizó el laudo; $\mathrm{O}$

(b) la parte contra la cual se invoca el laudo no recibió la debida notificación del nombramiento del árbitro o del procedimiento de arbitraje o de lo contrario no pudo presentar su caso; $\mathrm{O}$

(c) El laudo se ocupa de una diferencia que no se contempla o no está comprendida en los términos de la sumisión al arbitraje, o que contiene decisiones sobre asuntos fuera del alcance de la sumisión al arbitraje, siempre que, si las decisiones sobre asuntos sometidos a arbitraje pueden separarse de los no presentados, la parte del laudo que contiene decisiones sobre asuntos sometidos a arbitraje puede ser reconocida y ejecutada; $\mathrm{O}$ 
99. Sexto, la expansión de la doctrina a los no jueces siempre tuvo lugar en el contexto de la rúbrica e incidente historicidad del proceso judicial. Ni los elementos de ese proceso ni sus fundamentos históricos forman parte del arbitraje comercial internacional. Por lo tanto, la transposición de la inmunidad judicial a la inmunidad del árbitro, con la fuerza sólo de una analogía superficial relativa a aspectos aparentemente compartidos de adjudicación que, de hecho, no pueden resistir un análisis sostenido, es conceptualmente defectuoso y conduce a un funcionamiento práctico adverso. Los males de la sobreprotección no pueden ser vigilados.

100. Estas consecuencias, a su vez, dan lugar a mayores gastos, ineficiencias, preocupaciones materiales de divulgación y preguntas relativas a la legitimidad del proceso. El estándar "necesario para el proceso judicial" es completamente extrínseco a los procedimientos arbitrales.

101. En séptimo lugar, la consecuencia práctica de injertar la inmunidad judicial en los árbitros internacionales conduce a una disidencia sistemática de los principios más fundamentales y sacrosantos que el arbitraje pretende no sólo para salvaguardar sino avanzar: eficiencia y conveniencia. La sobreprotección derivada de la inmunidad absoluta provoca un cambio de costos imprevisto e involuntario. Como se ha señalado, ${ }^{111}$ la sobreprotección fomenta la cobertura de riesgos por parte de los árbitros, así como la proliferación y aplicación de un criterio subjetivo propicio para la no divulgación y el abuso de discreción.

102. Octavo y finalmente, la adjudicación judicial es razonable y cuidadosamente restringida. ${ }^{112}$ Incluso el estándar liberal del derecho consuetudinario de los Estados Unidos del "abuso de discreción" genera controles considerables sobre las resoluciones interlocutorias y dispositivas. ${ }^{113}$ Estas restricciones de responsabilidad de la apelación minimizan la necesidad de acciones de daños civiles privados como un medio para desalentar y controlar la mala conducta judicial intencional o negligente. Los árbitros no son susceptibles a los imperativos de una rendición de cuentas análoga, mucho menos idéntica. Por el contrario, la discreción del árbitro es práctica y teóricamente absoluta. ${ }^{114}$ Además, además de la naturaleza desenfrenada del poder inherente de la discreción del árbitro, el arbitraje carece de recurso de apelación. ${ }^{115}$

(d) la composición de la autoridad arbitral o el procedimiento arbitral no estaba de acuerdo con el acuerdo de las partes, o, en su defecto, no estaba de acuerdo con la ley del país donde se llevó a cabo el arbitraje; $\mathrm{O}$

Y El premio aún no ha sido vinculante para las partes, o ha sido revocada o suspendido por una autoridad competente del país en el que, o bajo la ley de la cual, se hizo ese laudo.

2. El reconocimiento y la ejecución de un laudo arbitral también podrán denegarse si la autoridad competente del país en el que se solicita el reconocimiento y la ejecución constata que:

un El objeto de la diferencia no es capaz de liquidación por arbitraje bajo la ley de ese país; $\mathrm{O}$

b El reconocimiento o la ejecución de la adjudicación sería contrario a la política pública de ese país.

Convención de Nueva Yorko.

${ }^{111}$ Supra en $\uparrow \uparrow$ 22, 49.

${ }^{112} I d$.

${ }^{113}$ Véase, por ejemplo., Commonwealth v. Chism, 476 Misa. 171 (2017); Herman v. Hartford Life \& Ins. co., 508 F. App'x 923 (11 ${ }^{\circ}$ CIR. 2013); Reaves v. Tucker, 800 S. E. 2D 188 (va. CT. app. 2017).

114 Véase Pedro J. Martínez-Fraga, Developing Equipoise between Party-Autonomy and the Inherent Power of Arbitrator Authority in the Gathering of Evidence in International Arbitration, En InHEREnt Powers of Arbitrators, 209 - 45 (Franco Ferrari \& Friedrich Rosenfeld Eds., 2018).

${ }^{115}$ Es la ley de la hornbook que los laudos arbitrales no son apelables. Sólo pueden ser reservados de conformidad con la legislación nacional del asiento (no necesariamente sede) del procedimiento de arbitraje. Así, a modo de ejemplo, la ley federal de arbitraje (9 U.S.C. $§ ~ § 1-14$ (1964)), en la sección 10 se establece el caso solamente en cualquiera de los siguientes Cinco Motivos: En cualquiera de los siguientes casos, el Tribunal de los Estados Unidos en y para el distrito en el que se hizo el laudo puede hacer una orden para descartar el laudo por solicitud de cualquier parte en el arbitraje.

(1) cuando el laudo haya sido adquirido por corrupción, fraude o medios indebidos;

(2) donde haya habido evidente parcialidad o corrupción en los árbitros, o cualquiera de ellos;

(3) cuando los árbitros fueran culpables de mala conducta al negarse a posponer la audiencia, por la causa suficiente demostrada, o al negarse a escuchar pruebas pertinentes y materiales para la controversia; o de cualquier otro mal comportamiento por el cual los derechos de cualquier parte hayan sido perjudicados; o

(4) donde los árbitros excedieron sus poderes, o los ejecutaron tan imperfectamente que no se hizo un laudo mutuo, definitivo y sobre el tema presentado. 
103. Estas premisas, sin embargo, no han desempeñado papel alguno en la calificación o la templanza de la importación sin restricciones de la historicidad y los elementos doctrinales de la inmunidad judicial, en los procedimientos arbitrales. Los poderes seductores de una analogía ostensiblemente atractiva no pueden subestimarse. El brillo de la función resolutoria, incluso dentro del marco idiosincrásico de un procedimiento arbitral, distrae de los diferenciadores más sustantivos, pero menos evidentes. Lo que sutilmente apareció, por primera vez, como "la aplicación ${ }^{116}$ de la doctrina de la inmunidad judicial a los árbitros," se convirtió en "la inmunidad del árbitro" del derecho consuetudinario. ${ }^{117}$

\section{Conclusión}

104. La historia enseña que, de hecho, el rey a menudo hace mal a sus súbditos, y tal vez con mayor regularidad, concibe la maldad. También aprendemos que, como en la era de la reconstrucción de la post guerra civil de Estados Unidos, existía un imperativo, y ciertamente uno justificado por la razón y la equidad, de fortalecer los fundamentos doctrinales de lucha de la institución judicial, asediada social, política y económicamente, cuyo trabajo era salvar la Unión y navegar por las aguas no codificadas de la aplicación de las enmiendas de la reconstrucción de la guerra civil.

105. Las relaciones de raza eran menos que claras en ese momento, incluso más de lo que son hoy en día. La configuración de una fuerza laboral posterior a la guerra civil era una completa desconocida. ¿Quién reemplazaría el trabajo de los esclavos? ¿Esto era posible? El estatuto y el significado sustantivo conceptual del término "ciudadano" suscitan interrogantes y generan incertidumbres para las que no hay respuestas o principios guiadores claros. Lo único que quedaba y parecía cierto era la existencial necesidad de tener un sistema judicial con la legitimidad suficiente para mantener unida a una nación con cicatrices. La inmunidad judicial se desarrolló legítimamente como una doctrina absoluta durante un período de relatividad fundacional.

106. Una revisión de las autoridades seminales establece múltiples capas de suposiciones no probadas y análisis equivocados, culminando en una doctrina de derecho común de la inmunidad absoluta del árbitro, indistinguible de su contraparte de primogenitura judicial.

(b) si se descarta un laudo y el momento en el que el acuerdo requirió que se hiciera el laudo no ha expirado, el Tribunal podrá, a su discreción, dirigir una re-audiencia por los árbitros.

La subsección (4) (c) proporciona un ejemplo del amplio Asistente de alcance para Cualquier procedimiento judicial debido a la medida en que tales acciones pueden hacer frente a los no-partes, en contraste con el arbitraje en virtud del cual los árbitros no tienen jurisdicción sobre los no-partes. De hecho, incluso con el limitado propósito de desalojar un laudo, un tribunal puede entretener documentos para caso presentados por no partes en el arbitraje, siempre y cuando se cumplan las normas rudimentarias permanentes. La sección 4) c) dice así:

(c) El Tribunal de distrito de los Estados Unidos para el distrito en el que se hizo un laudo que se emitió de conformidad con la sección 590 del título 5 puede hacer una orden de desalojo de la adjudicación sobre la aplicación de una persona, que no sea una parte en el arbitraje, que se ve afectada negativamente o agraviado por el laudo, si el uso del arbitraje o el laudo es claramente incompatible con los factores establecidos en la sección 582 del título 5.

Id.

Además de la ausencia de derechos de apelación y sólo la revisión para anular el laudo por motivos estrechos, mejorando así la necesidad de acciones privadas por daños civiles como medio para desalentar y controlar la mala conducta del árbitro, en los Estados Unidos, por ejemplo, las partes en un arbitraje están proscritos a aceptar la inserción de cláusulas en los acuerdos de arbitraje que piden un examen de apelación en cualquier terreno. Véase Hall Street Assocs., L.L.C. v. Mattel, Inc., 552 U.S. 576 (2008) (sosteniendo que "se extendería [la FAA] principios interpretativos básicos para ampliar los fundamentos declarados hasta el punto de la revisión probatoria y jurídica en general. Las secciones 10 y 11 , después de todo, abordan las desviaciones flagrantes del arbitraje acordado de las partes: "corrupción", "fraude", "parcialidad evidente", "mala conducta", "mal comportamiento", "exceder ... poderes, "error evidente del cálculo del material", "fallo material evidente", "laudo [s] sobre un asunto no presentado"; el único terreno con un enfoque más suave es el de ' iones imperfectos ', y un tribunal puede corregirlos sólo si van a ' [una] cuestión de forma que no afecte a los méritos ").

116 Supra qฯ $15-16,25,50-56,83$ - 91 .

${ }^{117} I d$. 
107. La doctrina de la inmunidad judicial fue transportada al espacio del arbitraje sobre la superficie de un argumento con base en la analogía, que no intentó examinar las diferencias fundamentales entre las políticas pertenecientes al ejercicio por el Estado de la soberanía judicial y la contrastante adjudicación de disputas privadas entre ciudadanos individuales.

108. La doctrina de inmunidad del árbitro se desarrolló de maneras que son intrigantes. La metodología comenzó, por vez primera, con una premisa falsa basada en el argumento por analogía; es decir, la adjudicación del árbitro es materialmente indistinguible de la adjudicación judicial. La analogía como instrumento conceptual de análisis se asumió y nunca se probó. La historicidad relativa al desarrollo de una doctrina de la inmunidad judicial absoluta nunca se consideró en el segundo paso de la metodología aplicada en el desarrollo de la doctrina de inmunidad del árbitro.

109. Este segundo paso consistió en aplicar la inmunidad judicial de las acciones civiles a los árbitros. Cómo, cuándo y en qué circunstancias se concedió a la inmunidad judicial una protección absoluta contra las reivindicaciones civiles, nunca formó parte del análisis. La posición del poder judicial como tercera rama del gobierno nunca se comparó con el modesto papel que tiene el arbitraje. El arbitraje, no importa cuán pragmático sea, no es un ejercicio de soberanía. No puede ser un pilar del Estado. 